\title{
Dynamics of Bacterial Community Structure in the Rhizosphere and Root Nodule of Soybean: Impacts of Growth Stages and Varieties
}

\author{
Soo-In Sohn ${ }^{1, *}$, Jae-Hyung Ahn ${ }^{2}{ }^{\mathbb{D}}$, Subramani Pandian ${ }^{1}{ }^{\mathbb{D}}$, Young-Ju Oh ${ }^{3}$, Eun-Kyoung Shin ${ }^{1}$, \\ Hyeon-Jung Kang ${ }^{1}$, Woo-Suk Cho ${ }^{1}$, Youn-Sung Cho ${ }^{1}$ and Kong-Sik Shin ${ }^{4}$
}

check for

updates

Citation: Sohn, S.-I.; Ahn, J.-H.; Pandian, S.; Oh, Y.-J.; Shin, E.-K.; Kang, H.-J.; Cho, W.-S.; Cho, Y.-S.; Shin, K.-S. Dynamics of Bacterial Community Structure in the Rhizosphere and Root Nodule of Soybean: Impacts of Growth Stages and Varieties. Int. J. Mol. Sci. 2021, 22, 5577. https://doi.org/10.3390/ ijms22115577

Academic Editor: Michela Schiavon

Received: 23 April 2021

Accepted: 22 May 2021

Published: 25 May 2021

Publisher's Note: MDPI stays neutral with regard to jurisdictional claims in published maps and institutional affiliations.

Copyright: (c) 2021 by the authors. Licensee MDPI, Basel, Switzerland. This article is an open access article distributed under the terms and conditions of the Creative Commons Attribution (CC BY) license (https:// creativecommons.org/licenses/by/ $4.0 /)$.
1 Department of Agricultural Biotechnology, National Institute of Agricultural Sciences, Jeonju 54874, Korea; pandiannsp7@gmail.com (S.P.); novis7@korea.kr (E.-K.S.); happykorean@korea.kr (H.-J.K.); phyto@korea.kr (W.-S.C.); younsung@korea.kr (Y.-S.C.)

2 Department of Agricultural Biology, National Institute of Agricultural Sciences, Jeonju 55365, Korea; hyungz@korea.kr

3 Institute for Future Environmental Ecology Co., Ltd., Jeonju 54883, Korea; 50joo@hanmail.net

4 Audit and Inspection Office, Rural Development of Administration, Jeonju 54875, Korea; kongsiks@korea.kr

* Correspondence: sisohn@korea.kr; Tel.: +82-063-238-4712

Abstract: Bacterial communities in rhizosphere and root nodules have significant contributions to the growth and productivity of the soybean (Glycine max (L.) Merr.). In this report, we analyzed the physiological properties and dynamics of bacterial community structure in rhizosphere and root nodules at different growth stages using BioLog EcoPlate and high-throughput sequencing technology, respectively. The BioLog assay found that the metabolic capability of rhizosphere is in increasing trend in the growth of soybeans as compared to the bulk soil. As a result of the Illumina sequencing analysis, the microbial community structure of rhizosphere and root nodules was found to be influenced by the variety and growth stage of the soybean. At the phylum level, Actinobacteria were the most abundant in rhizosphere at all growth stages, followed by Alphaproteobacteria and Acidobacteria, and the phylum Bacteroidetes showed the greatest change. But, in the root nodules Alphaproteobacteria were dominant. The results of the OTU analysis exhibited the dominance of Bradyrhizobium during the entire stage of growth, but the ratio of non-rhizobial bacteria showed an increasing trend as the soybean growth progressed. These findings revealed that bacterial community in the rhizosphere and root nodules changed according to both the variety and growth stages of soybean in the field.

Keywords: bacteria; community composition; growth stage; rhizosphere; root nodule; soybean; $16 \mathrm{~S}$ rRNA gene

\section{Introduction}

Soybeans (Glycine max (L.) Merr.) are one of the world's most valuable crops, yielding 300 million tons per year [1]. It was first cultivated in China and then spread to other parts of the globe [2]. The global soybean cultivation area is now 128.22 million ha, up 1.9 percent year on year [3]. The use of chemical fertilizers result in environmental perturbations like eutrophication in rivers and lakes as well as global warming. Therefore, we must consider the environmental issues along with the yield for the sustainable agricultural production. Soybeans do not need much fertilizer because they have a symbiotic relationship with rhizobia and arbuscular mycorrhizal fungi, but unwantedly, a lot of fertilizer is used in soybean cultivation. The effective use of rhizosphere microorganisms for the desirable growth of soybeans is necessary for sustainable agricultural production. Biofertilizers containing specific strains of plant growth-promoting rhizobacteria (PGPR) have been used for decades to increase plant nutrient use efficiency and reduce the use of chemical fertilizers and pesticides [4]. Initially, applied biofertilizer interacts with rhizosphere and root-associated microbes and later successfully colonize the roots to benefit the plant [5-9]. 
Understanding the dynamics and diversity of native microbial communities associated with the roots and rhizosphere is needed to gain insight into such interactions [9-11].

Rhizosphere soil is defined as a zone that contains soil that has been affected by roots as well as microorganisms colonizing the root structure [12-14]. It acts as an initial filter for subsets of microorganisms that colonize the root as endophytes [15]. Plants can actively modulate the assembly of beneficial microbiome $[6,16,17]$. Microorganisms inhabiting the rhizosphere play an important role in plant health and defense [18-20], stress response [21], nutrition [22,23], and plant growth promotion [24]. The plant root exudates mediate interactions between microbial communities present in the roots and rhizosphere [25-27]. Plant roots release $5-21 \%$ of photosynthetically fixed carbon in the forms of soluble sugars, amino acids, and secondary metabolites, which are used by the rhizosphere microbial communities [26-29]. The community structure of rhizosphere is affected by the source and amount of substances released from the roots [14], root architecture [30], species or genotype of plants [23,31,32], and growth stages [33].

Since soybean is an important nutritional and economic crop it is imperative to study the dynamics of rhizosphere community composition with high-resolution profiling methods. High-throughput sequencing technology enabled us to study plant-associated microbial communities at high resolution. Studies on rhizosphere microorganisms associated with plant roots have been conducted in Arabidopsis thaliana, Hordeum vulgare [15,16,34,35], corns, and soybeans $[22,36]$. Despite these fundamental studies, the truth is that there is a scarcity of research on the roots and rhizosphere microorganisms in commercial and non-model plants. Since soybeans have a symbiotic relationship with nitrogen-fixing $\left(\mathrm{N}_{2}\right)$ rhizobia and enhances its $\mathrm{N}_{2}$-fixing capability, a number of studies have been conducted to better understand the processes and signaling pathways [24,37-39]. Based on the previous studies, the effective interaction between soybeans and beneficial root nodule bacteria improves plant health, yield, and resilience [24,39]. The beneficial effects of Bradyrhizobium spp. on the soybean nodule formation and $\mathrm{N}_{2}$ fixation are well known and members of the Bradyrhizobium genus have been confirmed to influence soybean growth and yield [40,41]. However, little is known about the variation in the residential bacterial population in root nodules based on the growth stage. As the first step in elite soybean breeding, understanding the diversity of the root nodule microbiome is crucial. The frequency and ecotypes of atypical bacterial taxa in root nodules of soybean and other legume plants have been identified using culture-dependent sampling methods, and microbiome sequencing [42-44]. Despite their findings, more concerns remain such as the influence of growth stages, cultivars, and their mechanisms in the dynamics of microbial community composition.

To fill these lacunae, we examined the interactions between soybeans and microorganisms, soybeans and root nodule bacteria, and rhizosphere and root nodule bacteria in the field environment. Therefore, population-level BioLog substrate utilization assay was used to examine physiological properties of microbial species, and $16 \mathrm{~S}$ rRNA gene sequencing was used to assess the dynamics of community composition between rhizosphere and root nodule bacteria by the variety and growth stages of soybean.

\section{Materials and Methods}

\subsection{Plant Materials}

Glycine max (L.) Merr. cv. Kwangan (KA), Poongsannamul (PS), Poongwon (PW), and Taekwang (TK) used in this study were obtained from the National Institute of Crop Science, Jeonju, South Korea.

\subsection{Field Construction and Soil Sample Preparation}

The experimental plot for assessing the bacterial community structure in four soybean varieties (KA, PS, PW, and TK), was established in the field of the National Institute of Agricultural Sciences, Rural Development Administration, Jeonju, Korea. For each soybean variety, three replicates of the experimental plot were made. Each experimental plot was $4 \times 4 \mathrm{~m}^{2}$ in size. Three replicates of soil samples were collected from the soils prior to 
planting (bulk soil), as well as soil samples from the rhizosphere and root nodules of each stage, including vegetative (V2) and reproductive stages (R1, R3, R5, and R7). Morphology of plants and root nodules in different varieties and growth stages was shown in Figure 1.

KA

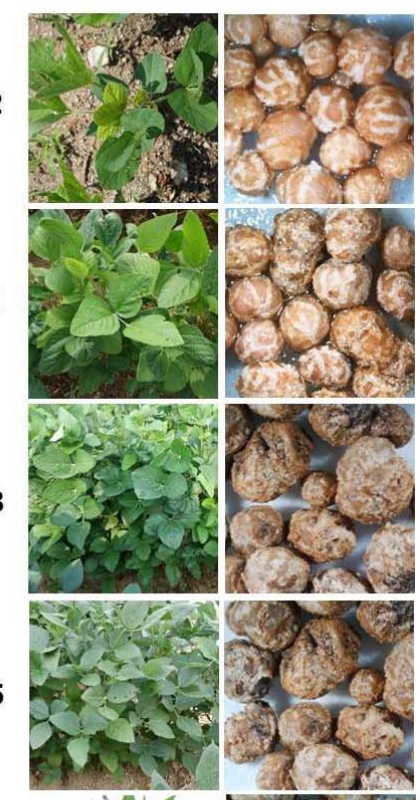

R7

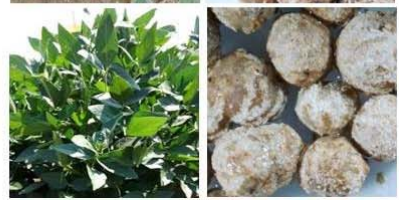

PS
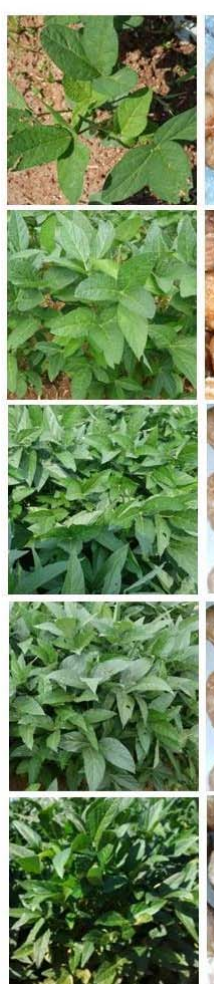
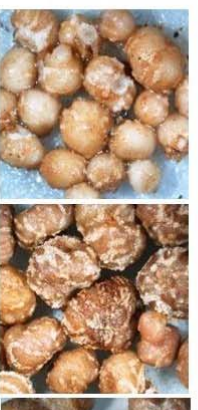

PW

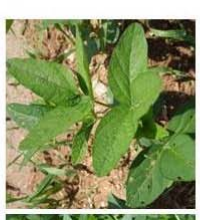

5
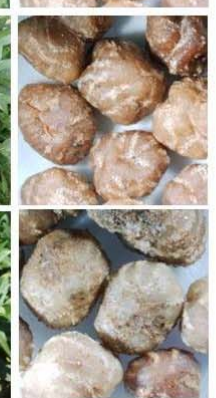
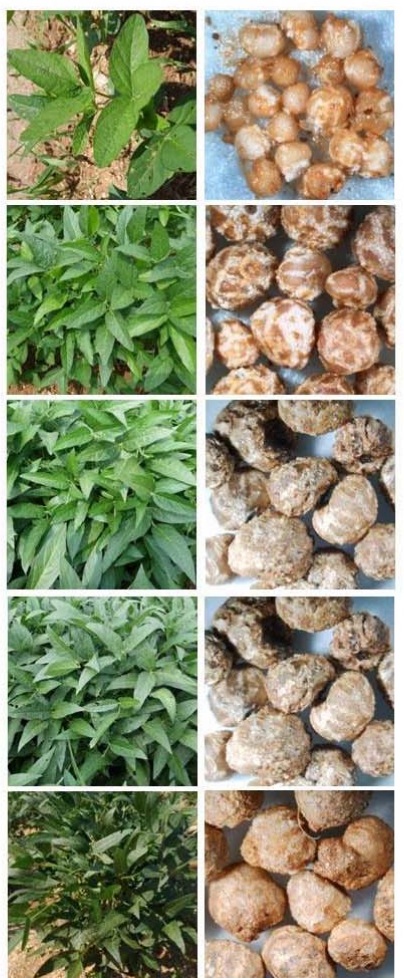

TK

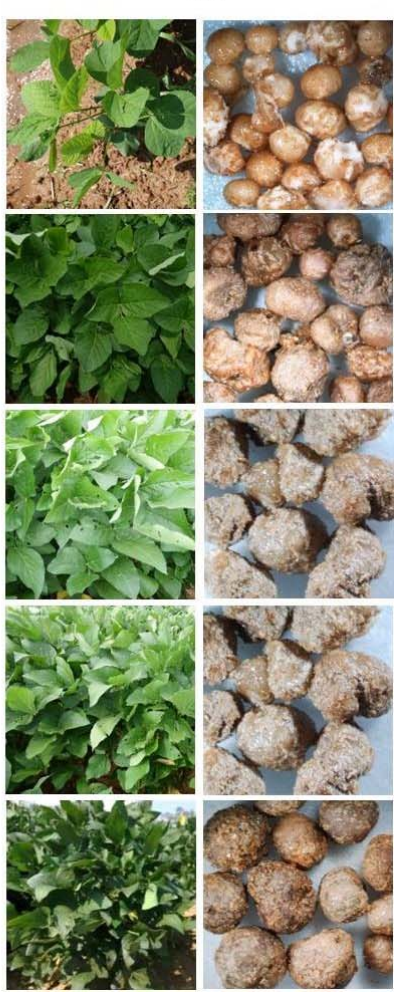

Figure 1. Morphology of four varieties of plants and root nodules based on the various growth stages (V2. R1, R3, R5, R7) of soybean. KA, Kwangan; PS, Poongsannamul; PW, Poongwon; TK, Taekwang.

To obtain rhizosphere soil, we collected soybean with its root, completely removed bulk soil and then collected soil that is attached to the root as much as possible using sterile brushes. Rhizosphere soil samples were immediately transported to the laboratory in a cool container $\left(4^{\circ} \mathrm{C}\right)$ within $2 \mathrm{~h}$. Immediately after the homogenization and passing through a $2 \mathrm{~mm}$ sieve, $1.5 \mathrm{~g}$ of each sample was used in the BioLog substrate utilization assay to avoid any changes in microbial communities while storing soils. The residual soil was preserved at $-30^{\circ} \mathrm{C}$ until subsequent DNA extraction.

\subsection{Root Nodule Preparation}

Soybean root nodules were removed from roots, washed, and dried overnight at $65{ }^{\circ} \mathrm{C}$ (oven-dried), then stored at room temperature in vials containing silica gel until experiment time [45]. Initially, the root nodule was rehydrated in sterile water until completely swollen, then treated with 95\% ethanol for 5 min, sterilized with 3\% sodium hypochlorite solution for $3 \mathrm{~min}$, and washed 5 times with sterile distilled water for DNA extraction. To obtain rhizobial cell suspension, each root nodule was loaded into a $5 \mathrm{~mL}$ micro centrifuge tube, $0.1 \mathrm{~mL}$ of TE buffer was added, and mechanically pressed using a sterile plastic pipette tip. The cell suspension was transferred to a new tube and the cells were collected by a simple centrifugation process at $15,000 \mathrm{rpm}$ for $5 \mathrm{~min}$ at $4{ }^{\circ} \mathrm{C}$. The supernatant was removed, and DNA was extracted using rhizobial cells.

\subsection{Community-Level Physiological Profiling (CLPP) Analysis}

The potential of the microbial community functions was investigated through CLPP analysis by inoculating soil samples into each well of the EcoPlate (Biolog, Hayward, CA, 
USA). For this experiment, soil samples were dissolved in sterile water at a 1:10 $(w / w)$ ratio and stirred for $10 \mathrm{~min}$ at $200 \mathrm{rpm}$. Then, $150 \mu \mathrm{L}$ of the supernatant was taken to fill each EcoPlate wells. After that, it was incubated at $20^{\circ} \mathrm{C}$, and the color change in each well was measured and analyzed using Multiskan Ascent at $595 \mathrm{~nm}$ wavelength in every $2 \mathrm{~h}$ for $24 \mathrm{~h}$ (Thermo Labsystems, Finland). Each EcoPlate was divided into three identical zones, serving as replicates, and the absorbance value of each carbon source was corrected by subtracting the absorbance value of the control well (without any carbon substrate); negative values were set to zero. The mean of the 31 corrected values was used to measure Average Well Color Development (AWCD) for each replication and sampling time [46,47].

\subsection{PCR Amplification and Illumina Sequencing}

Metagenomic DNA was extracted from bulk soils, rhizosphere soils, and root nodules of soybeans using the Fast DNA Spin Kit (Qbiogen, Carlsbad, CA, USA) according to the manufacturer's instructions. PCR amplification was carried out with extracted DNA using universal eubacterial primers targeting the V3-V4 hypervariable regions of the $16 \mathrm{~S}$ rRNA gene. For bacterial amplification, primers of 341F (5'-TCGTCGGCAGCGTCAGATGTGTATAAGAGACAG-CCTACGGGNGGCWGCAG-3'; underlining sequence indicates the target region primer) and 805R (5'-GTCTCGTGGGCTCGG-AGATGTGTATAAGAGACAG-GACTACHVGGGTATCTAATCC- $3^{\prime}$ ). The amplifications were carried out under the following conditions: initial denaturation at $95^{\circ} \mathrm{C}$ for $3 \mathrm{~min}$, followed by 25 cycles of denaturation at $95{ }^{\circ} \mathrm{C}$ for $30 \mathrm{~s}$, primer annealing at $55^{\circ} \mathrm{C}$ for $30 \mathrm{~s}$, and extension at $72{ }^{\circ} \mathrm{C}$ for $30 \mathrm{~s}$, with a final extension at $72{ }^{\circ} \mathrm{C}$ for $5 \mathrm{~min}$. Then, secondary amplification for attaching the Illumina NexTera barcode was performed with i5 forward primer $\left(5^{\prime}\right.$ AATGATACGGCGACCACCGAGATCTACAC-XXXXXXXX -TCGTCGGCAGCGTC-3'; $X$ indicates the barcode region) and i7 reverse primer (5'-CAAGCAGAAGACGGCATACGAGAT-XXXXXXXX-TCTCGTGGGCTCGG-3'). The condition of secondary amplification is equal to former one except the amplification cycle set to 8 .

The PCR product was confirmed by using agarose gel (1\%) electrophoresis and visualized under a Gel Doc system (BioRad, Hercules, CA, USA). The amplified products were purified with the CleanPCR (CleanNA, The Netherlands). Equal concentrations of purified products were pooled together and removed short fragments (non-target products) with CleanPCR (CleanNA, The Netherlands). The quality and product size were assessed on a Bioanalyzer 2100 (Agilent, Palo Alto, CA, USA) using a DNA 7500 chip. Mixed amplicons were pooled and the sequencing was performed using an Illumina MiSeq Sequencing platform (Illumina, San Diego, CA, USA) at Chunlab, Inc. in Seoul, South Korea, according to the manufacturer's instructions.

\subsection{Bioinformatics Analyses}

Processing raw reads starts with quality check and filtering of low quality $(<\mathrm{Q} 25)$ reads by Trimmomatic 0.32 . After $\mathrm{QC}$ pass, paired end sequence data are merged together using PANDAs eq. Primers are then trimmed with ChunLab's in house program at a similarity cutoff of 0.8 . Nonspecific amplicons that do not encode $16 \mathrm{~S}$ rRNA are detected by HMMER's hmmsearch program with $16 \mathrm{~S}$ rRNA gene profiles. Sequences are de-noised using DUDE Seq and non-redundant reads are extracted by UCLUST clustering. The EzBio Cloud database is used for taxonomic assignment using USEARCH (8.1.1861_i86linux32) followed by more precise pairwise alignment UCHIME and then on chimeric 16S rRNA gene database from EzBioCloud are used to detect chimera on reads that contain a less than $97 \%$ best hit similarity rate. Sequence data are then clustered using CD-HIT and UCLUST. The alpha diversity indices and rarefaction curves are estimated by in-house code.

\subsection{Statistical Analysis}

Results are presented with the mean \pm standard deviations of triplicate experiments. One-way analysis of variance (ANOVA) with Tukey's HDS (honestly significant difference) 
test $(p \leq 0.05)$ was performed with GraphPad Prism ver. 5.0 (GraphPad Software, Inc., San Diego, CA, USA).

\section{Results}

\subsection{BioLog Substrate Utilization Assay}

The BioLog substrate utilization assay was carried out with bulk soil and rhizosphere soil of various growth stages (V2, R1, R3, R5, and R7) of all the four soybean varieties. The color intensity was determined by calculating the average well color development (AWCD). When the same amount of soil was used, the AWCD of rhizosphere soil was 1.5-3.0 times higher than that of bulk soil throughout the growth stages of soybean (Figure 2A-F). Similarly, differences in the varieties of soybean also found to be influenced in the values of AWCD (Figure 2A-F). These results indicating that the metabolic capabilities of the rhizosphere soil were higher than those of the bulk soil and the physiological profiles of the two classes of soil were very different (Figure 2A-F; Table S1)
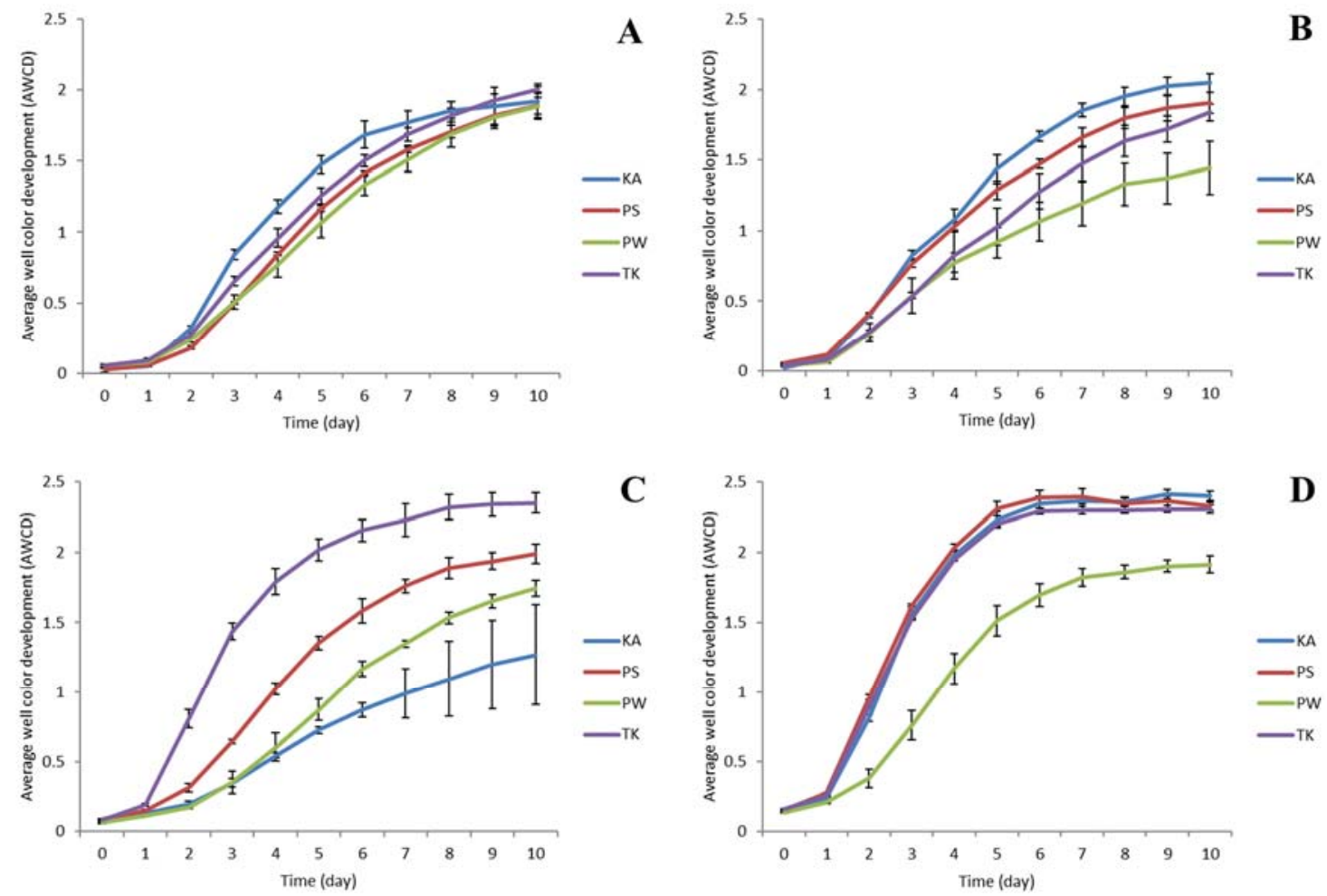

D
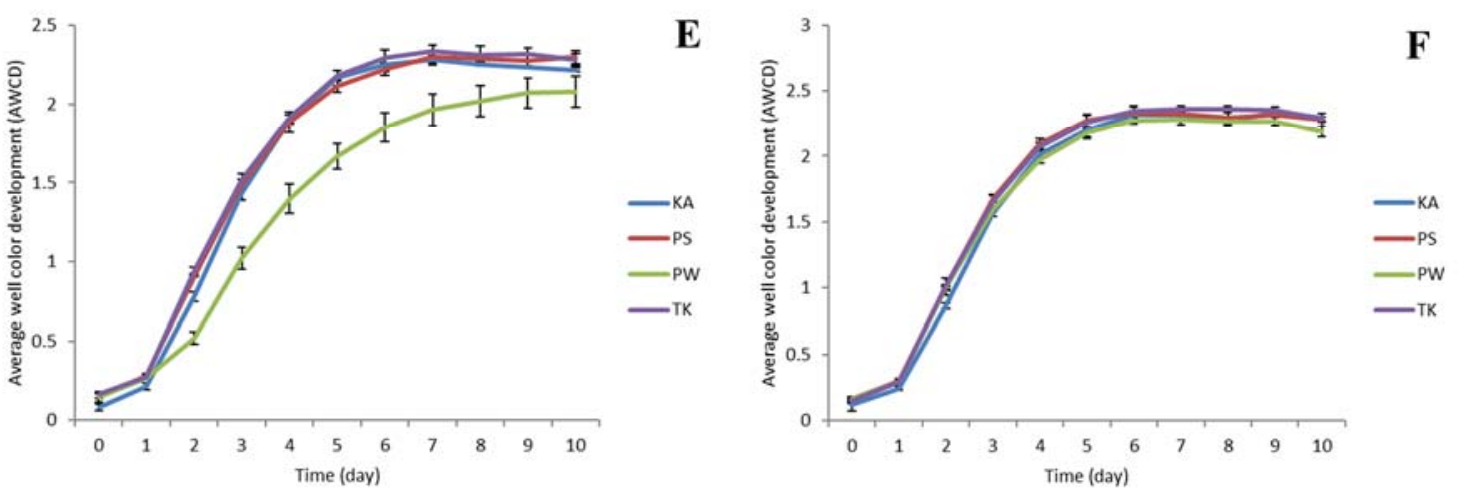

Figure 2. Changes of AWCD according to incubation time of rhizosphere soil microbes based on the growth stages (V2, R1, R3, R5, R7) of soybean. Values indicate mean $(n=3) \pm$ standard deviation. (A), Soil before planting soybean; (B), V2 stage; (C), R1 stage; (D), R3 stage; (E), R5 stage; (F), R7 stage. 


\subsection{Alpha Diversity Analysis}

A total of 721,643 sequences was obtained from 12 soil samples (soil where 4 varieties of KA, PS, PW, and TK are to be planted, 3 repetitions) of the bulk soil. A total of $3,433,735$ sequences was obtained from 60 soil samples (4 varieties same as the bulk soil, 3 repetitions, 5 stages of soybean growth: V2, R1, R3, R5, and R7) of the rhizosphere soil. A total of 2,617,554 sequences was obtained from 60 root nodule extracted DNA samples ( 4 varieties, 3 repetitions, and 5 stages of soybean growth: V2, R1, R3, R5, and R7). These reads were clustered into 13,628 OTUs (Table S2). The alpha diversity of rhizosphere soil and the root nodule bacteria was affected by the variety and growth stage of the soybean (Tables 1 and 2; Figure S1A-F and Figure S2A-F). In the rhizosphere, the Sobs, Chao1, and ACE, which denote species richness (number of OTUs), that increased in the V2 and R1 stages as compared with the bulk soil where the soybean was not planted. Subsequently, these decreased from the R3 to R7 stages (Figure S1A-C). The Shannon, InvSimpson, and NPShannon, which refer to the species diversity index, showed a similar trend and increased until the V2 or R1 stage and decreased from the R3 to R7 stages (Figure S1D-F). Contrarily, the alpha diversity of the root nodule bacteria showed a different trend from the bulk and rhizosphere soil (Table 2; Figure S2A-C). The Shannon, InvSimpson, and NPShannon all seemed to increase from the V2 to R7 levels, similar to the Sobs, Chao1, and ACE (Table 2; Figure S2A-F).

Table 1. Diversity indices of bacterial community in the rhizosphere soil of 4 varieties of soybean.

\begin{tabular}{|c|c|c|c|c|c|c|c|c|}
\hline Variety & GS & Sobs & Coverage(\%) & Chao & Ace & Shannon & Invsimpson & Npshannon \\
\hline \multirow{6}{*}{ KA } & BS & $2110.0 \pm 65.4 a$ & $0.9 \pm 0.0$ & $2875.1 \pm 177.6 \mathrm{ab}$ & $3037.2 \pm 169.4 \mathrm{a}$ & $6.1 \pm 0.0 \mathrm{ab}$ & $84.1 \pm 4.3 \mathrm{ab}$ & $6.3 \pm 0.0 \mathrm{a}$ \\
\hline & $\mathrm{V} 2$ & $2255.0 \pm 55.5 a$ & $0.9 \pm 0.0$ & $3026.2 \pm 223.6 b$ & $3181.8 \pm 222.3 a$ & $6.3 \pm 0.1 b$ & $114.8 \pm 32.7 \mathrm{bc}$ & $6.5 \pm 0.1 \mathrm{a}$ \\
\hline & $\mathrm{R} 1$ & $2230.7 \pm 183.9 \mathrm{a}$ & $1.0 \pm 0.0$ & $2826.2 \pm 475.8 \mathrm{ab}$ & $2962.2 \pm 524.9 \mathrm{a}$ & $6.4 \pm 0.1 b$ & $140.4 \pm 17.5 b d$ & $6.6 \pm 0.1 a$ \\
\hline & R3 & $2004.7 \pm 152.7 \mathrm{ab}$ & $1.0 \pm 0.0$ & $2721.0 \pm 333.3 \mathrm{ab}$ & $3039.6 \pm 539.2 \mathrm{a}$ & $5.8 \pm 0.4 \mathrm{ab}$ & $59.4 \pm 30.5 \mathrm{ac}$ & $6.0 \pm 0.4 \mathrm{ab}$ \\
\hline & R5 & $2044.7 \pm 117.9 \mathrm{ab}$ & $1.0 \pm 0.0$ & $2621.8 \pm 123.2 \mathrm{ab}$ & $2755.7 \pm 133.5 a$ & $6.1 \pm 0.3 \mathrm{ab}$ & $79.1 \pm 46.1 \mathrm{ab}$ & $6.2 \pm 0.3 \mathrm{ab}$ \\
\hline & R7 & $1612.3 \pm 274.3 b$ & $1.0 \pm 0.0$ & $2185.0 \pm 287.8 \mathrm{a}$ & $2308.4 \pm 261.1 \mathrm{a}$ & $5.0 \pm 0.9 \mathrm{ac}$ & $30.2 \pm 25.7 \mathrm{a}$ & $5.1 \pm 0.9 b$ \\
\hline \multirow{6}{*}{ PS } & BS & $2024.0 \pm 128.3 a$ & $1.0 \pm 0.0$ & $2689.3 \pm 239.2 \mathrm{a}$ & $2815.0 \pm 252.2 \mathrm{a}$ & $6.0 \pm 0.1 \mathrm{a}$ & $73.5 \pm 7.2 \mathrm{a}$ & $6.2 \pm 0.1 \mathrm{a}$ \\
\hline & V2 & $2335.0 \pm 183.4 \mathrm{a}$ & $0.9 \pm 0.0$ & $3156.0 \pm 546.0 \mathrm{a}$ & $3512.8 \pm 843.2 \mathrm{a}$ & $6.4 \pm 0.1 \mathrm{a}$ & $110.2 \pm 7.2 \mathrm{a}$ & $6.5 \pm 0.1 \mathrm{a}$ \\
\hline & R1 & $2397.7 \pm 191.6 a$ & $0.9 \pm 0.0$ & $3224.7 \pm 480.2 \mathrm{a}$ & $3387.5 \pm 514.2 \mathrm{a}$ & $6.5 \pm 0.1 \mathrm{a}$ & $147.2 \pm 64.3 a$ & $6.7 \pm 0.1 \mathrm{a}$ \\
\hline & R3 & $2076.3 \pm 113.9 a$ & $1.0 \pm 0.0$ & $2728.8 \pm 151.7 \mathrm{a}$ & $2852.6 \pm 145.1 \mathrm{a}$ & $6.0 \pm 0.3 a$ & $75.7 \pm 36.7 \mathrm{a}$ & $6.2 \pm 0.3 a$ \\
\hline & R5 & $2252.0 \pm 108.1 \mathrm{a}$ & $1.0 \pm 0.0$ & $2835.8 \pm 200.2 a$ & $2979.6 \pm 190.0 \mathrm{a}$ & $6.4 \pm 0.1 \mathrm{a}$ & $127.1 \pm 15.1 \mathrm{a}$ & $6.5 \pm 0.1 \mathrm{a}$ \\
\hline & R7 & $2055.3 \pm 257.5 a$ & $0.9 \pm 0.0$ & $2789.6 \pm 398.7 a$ & $2942.4 \pm 391.5 a$ & $6.1 \pm 0.4 a$ & $105.6 \pm 51.2 \mathrm{a}$ & $6.3 \pm 0.3 a$ \\
\hline \multirow{6}{*}{ PW } & BS & $2113.3 \pm 63.3 a$ & $0.9 \pm 0.0$ & $2836.3 \pm 88.0 \mathrm{a}$ & $2983.7 \pm 130.1 \mathrm{a}$ & $6.2 \pm 0.1 \mathrm{ab}$ & $98.3 \pm 23.4 a b$ & $6.3 \pm 0.1 \mathrm{ab}$ \\
\hline & $\mathrm{V} 2$ & $2182.3 \pm 446.2 \mathrm{a}$ & $0.9 \pm 0.0$ & $2952.6 \pm 926.4 a$ & $3284.5 \pm 1210.4 a$ & $6.2 \pm 0.4 \mathrm{ab}$ & $103.2 \pm 43.2 \mathrm{ab}$ & $6.4 \pm 0.4 b$ \\
\hline & $\mathrm{R} 1$ & $2380.7 \pm 309.2 \mathrm{a}$ & $0.9 \pm 0.0$ & $3321.0 \pm 697.2 \mathrm{a}$ & $3474.1 \pm 693.9 a$ & $6.4 \pm 0.2 \mathrm{a}$ & $149.5 \pm 46.1 \mathrm{a}$ & $6.6 \pm 0.2 b$ \\
\hline & R3 & $2062.7 \pm 68.5 a$ & $1.0 \pm 0.0$ & $2658.1 \pm 5.0 \mathrm{a}$ & $2783.4 \pm 8.1 \mathrm{a}$ & $6.1 \pm 0.2 \mathrm{ab}$ & $83.5 \pm 26.8 \mathrm{ab}$ & $6.2 \pm 0.2 \mathrm{ab}$ \\
\hline & R5 & $2066.7 \pm 185.0 \mathrm{a}$ & $1.0 \pm 0.0$ & $2661.0 \pm 324.6 \mathrm{a}$ & $2792.4 \pm 256.3 a$ & $6.2 \pm 0.1 \mathrm{ab}$ & $108.1 \pm 10.8 \mathrm{ab}$ & $6.3 \pm 0.1 \mathrm{ab}$ \\
\hline & R7 & $1862.3 \pm 101.7 \mathrm{a}$ & $1.0 \pm 0.0$ & $2617.1 \pm 82.4 a$ & $2881.8 \pm 347.0 \mathrm{a}$ & $5.4 \pm 0.6 b c$ & $31.3 \pm 23.6 b c$ & $5.5 \pm 0.6 \mathrm{ac}$ \\
\hline \multirow{6}{*}{ TK } & BS & $2063.3 \pm 123.2 \mathrm{ab}$ & $1.0 \pm 0.0$ & $2730.5 \pm 346.2 \mathrm{a}$ & $2844.0 \pm 336.1 \mathrm{a}$ & $6.1 \pm 0.1 \mathrm{ab}$ & $89.2 \pm 13.1 \mathrm{ab}$ & $6.3 \pm 0.1 a$ \\
\hline & $\mathrm{V} 2$ & $2246.7 \pm 115.9 a$ & $0.9 \pm 0.0$ & $3132.7 \pm 432.3 a$ & $3464.0 \pm 732.1 \mathrm{a}$ & $6.3 \pm 0.0 \mathrm{~b}$ & $102.7 \pm 2.0 \mathrm{~b}$ & $6.4 \pm 0.0 \mathrm{a}$ \\
\hline & R1 & $2212.3 \pm 186.2 a$ & $0.9 \pm 0.0$ & $3073.3 \pm 513.0 \mathrm{a}$ & $3375.9 \pm 756.7 a$ & $6.3 \pm 0.2 b$ & $104.6 \pm 51.3 b$ & $6.4 \pm 0.2 \mathrm{a}$ \\
\hline & $\mathrm{R} 3$ & $2105.0 \pm 52.8 \mathrm{ab}$ & $1.0 \pm 0.0$ & $2784.4 \pm 168.5 \mathrm{a}$ & $2909.4 \pm 174.7 \mathrm{a}$ & $6.2 \pm 0.1 \mathrm{ab}$ & $106.2 \pm 13.5 b$ & $6.4 \pm 0.1 \mathrm{a}$ \\
\hline & R5 & $2141.3 \pm 98.2 \mathrm{ab}$ & $1.0 \pm 0.0$ & $2714.2 \pm 202.7 \mathrm{a}$ & $2874.4 \pm 203.6 a$ & $6.2 \pm 0.1 \mathrm{ab}$ & $100.9 \pm 13.2 b$ & $6.4 \pm 0.1 \mathrm{a}$ \\
\hline & R7 & $1792.7 \pm 189.5 b$ & $1.0 \pm 0.0$ & $2447.5 \pm 270.0 \mathrm{a}$ & $2590.1 \pm 253.3 a$ & $5.3 \pm 0.8 \mathrm{ac}$ & $29.2 \pm 20.3 \mathrm{ac}$ & $5.4 \pm 0.7 \mathrm{~b}$ \\
\hline
\end{tabular}

GS, Growth stage of soybean (V2, R1, R3, R5, R7); BS, Bulk soil before planting 4 varieties of soybean; KA, Kwangan; PS, Poongsannamul; PW, Poongwon; TK, Taekwang. Values are Mean \pm SD from three replications, the significant differences based on Tukey's HDS test $(p \leq 0.05)$ were indicated with different letters. 
Table 2. Diversity indices of bacterial community in the root nodule of 4 varieties of soybean.

\begin{tabular}{|c|c|c|c|c|c|c|c|c|}
\hline Variety & GS & Sobs & $\begin{array}{c}\text { Coverage } \\
(\%)\end{array}$ & Chao & Ace & Shannon & Invsimpson & Npshannon \\
\hline \multirow{5}{*}{ KA } & $\mathrm{V} 2$ & $23 \pm 1.4 \mathrm{a}$ & $1.0 \pm 0.0$ & $33 \pm 3.6 \mathrm{a}$ & $46.8 \pm 15.1 \mathrm{a}$ & $0.5 \pm 0.1 \mathrm{ab}$ & $1.4 \pm 0.1 \mathrm{ab}$ & $0.5 \pm 0.1 \mathrm{ab}$ \\
\hline & $\mathrm{R} 1$ & $22 \pm 2.2 \mathrm{a}$ & $1.0 \pm 0.0$ & $37.7 \pm 3.8 \mathrm{a}$ & $55.8 \pm 8.0 \mathrm{a}$ & $0.2 \pm 0.1 \mathrm{a}$ & $1.1 \pm 0.1 b c$ & $0.2 \pm 0.1 b$ \\
\hline & $\mathrm{R} 3$ & $67.7 \pm 27.4 b$ & $1.0 \pm 0.0$ & $100.3 \pm 30.9 a$ & $139.2 \pm 32.5 a$ & $0.3 \pm 0.1 \mathrm{a}$ & $1.1 \pm 0.1 b c$ & $0.3 \pm 0.1 b$ \\
\hline & R5 & $38.0 \pm 17.1 \mathrm{ab}$ & $1.0 \pm 0.0$ & $60.8 \pm 40.3 a$ & $88.0 \pm 68.1 \mathrm{a}$ & $0.2 \pm 0.1 \mathrm{a}$ & $1.0 \pm 0.0 c$ & $0.2 \pm 0.1 b$ \\
\hline & R7 & $71.3 \pm 14.1 \mathrm{bc}$ & $1.0 \pm 0.0$ & $94.8 \pm 36.0 \mathrm{a}$ & $108.6 \pm 49.2 \mathrm{a}$ & $0.8 \pm 0.3 b$ & $1.5 \pm 0.2 \mathrm{a}$ & $0.9 \pm 0.3 \mathrm{ac}$ \\
\hline \multirow{5}{*}{ PS } & $\mathrm{V} 2$ & $32 \pm 9.2 \mathrm{a}$ & $1.0 \pm 0.0$ & $60.3 \pm 16.5 a$ & $73.9 \pm 13.2 \mathrm{a}$ & $0.2 \pm 0.1 \mathrm{a}$ & $1.1 \pm 0.0 \mathrm{a}$ & $0.2 \pm 0.1 \mathrm{a}$ \\
\hline & $\mathrm{R} 1$ & $31.3 \pm 11.0 \mathrm{a}$ & $1.0 \pm 0.0$ & $43.4 \pm 9.6 a$ & $56.3 \pm 4.2 \mathrm{a}$ & $0.2 \pm 0.1 \mathrm{a}$ & $1.1 \pm 0.1 \mathrm{a}$ & $0.2 \pm 0.1 \mathrm{a}$ \\
\hline & R3 & $53.0 \pm 6.2 a$ & $1.0 \pm 0.0$ & $82.0 \pm 8.0 \mathrm{a}$ & $85.1 \pm 12.6 \mathrm{a}$ & $0.2 \pm 0.1 \mathrm{a}$ & $1.1 \pm 0.0 \mathrm{a}$ & $0.2 \pm 0.1 \mathrm{a}$ \\
\hline & $\mathrm{R} 5$ & $28.0 \pm 14.2 \mathrm{a}$ & $1.0 \pm 0.0$ & $44.9 \pm 22.2 \mathrm{a}$ & $74.0 \pm 34.6 \mathrm{a}$ & $0.4 \pm 0.1 \mathrm{ab}$ & $1.2 \pm 0.1 \mathrm{a}$ & $0.4 \pm 0.1 \mathrm{ab}$ \\
\hline & R7 & $118.7 \pm 75.0 \mathrm{a}$ & $1.0 \pm 0.0$ & $138.5 \pm 91.4 a$ & $148.7 \pm 95.1 \mathrm{a}$ & $1.1 \pm 0.6 \mathrm{~b}$ & $1.6 \pm 0.4 a$ & $1.1 \pm 0.6 b c$ \\
\hline \multirow{5}{*}{ PW } & V2 & $31.5 \pm 0.5 a$ & $1.0 \pm 0.0$ & $46 \pm 7.7 \mathrm{a}$ & $65 \pm 17.6 a$ & $0.2 \pm 0.2 \mathrm{a}$ & $1.1 \pm 0.1 \mathrm{a}$ & $0.2 \pm 0.2 \mathrm{a}$ \\
\hline & $\mathrm{R} 1$ & $25.7 \pm 1.2 \mathrm{a}$ & $1.0 \pm 0.0$ & $34.5 \pm 6.7 \mathrm{a}$ & $43.5 \pm 10.6 \mathrm{a}$ & $0.1 \pm 0.1 \mathrm{a}$ & $1.1 \pm 0.1 \mathrm{a}$ & $0.2 \pm 0.1 \mathrm{a}$ \\
\hline & $\mathrm{R} 3$ & $41.3 \pm 8.7 \mathrm{a}$ & $1.0 \pm 0.0$ & $74.1 \pm 31.9 \mathrm{ab}$ & $83.9 \pm 31.5 a$ & $0.1 \pm 0.1 \mathrm{a}$ & $1.0 \pm 0.0 \mathrm{a}$ & $0.1 \pm 0.1 \mathrm{a}$ \\
\hline & R5 & $21.0 \pm 8.6 \mathrm{a}$ & $1.0 \pm 0.0$ & $24.3 \pm 9.7 \mathrm{a}$ & $34.8 \pm 14.8 \mathrm{a}$ & $0.1 \pm 0.1 \mathrm{a}$ & $1.1 \pm 0.1 \mathrm{a}$ & $0.1 \pm 0.1 \mathrm{a}$ \\
\hline & R7 & $83.0 \pm 25.2 b$ & $1.0 \pm 0.0$ & $121.3 \pm 37.0 \mathrm{~b}$ & $156.0 \pm 31.2 b$ & $0.6 \pm 0.5 \mathrm{a}$ & $1.3 \pm 0.3 \mathrm{a}$ & $0.6 \pm 0.5 \mathrm{a}$ \\
\hline \multirow{5}{*}{ TK } & $\mathrm{V} 2$ & $23.7 \pm 0.9 a$ & 10. \pm 0.0 & $48.4 \pm 12.6 \mathrm{ab}$ & $84.8 \pm 45.8 \mathrm{a}$ & $0.3 \pm 0.2 \mathrm{ab}$ & $1.2 \pm 0.1 \mathrm{a}$ & $0.3 \pm 0.2 \mathrm{ab}$ \\
\hline & $\mathrm{R} 1$ & $22.3 \pm 3.9 a$ & $1.0 \pm 0.0$ & $36.0 \pm 8.3 a$ & $46.1 \pm 17.9 a$ & $0.1 \pm 0.1 \mathrm{a}$ & $1.1 \pm 0.0 \mathrm{a}$ & $0.1 \pm 0.1 \mathrm{a}$ \\
\hline & R3 & $47.3 \pm 24.0 \mathrm{a}$ & $1.0 \pm 0.0$ & $70.9 \pm 23.0 \mathrm{ab}$ & $92.2 \pm 32.7 \mathrm{a}$ & $0.3 \pm 0.3 \mathrm{ab}$ & $1.2 \pm 0.2 \mathrm{a}$ & $0.3 \pm 0.3 a b$ \\
\hline & R5 & $29.3 \pm 18.2 \mathrm{a}$ & $1.0 \pm 0.0$ & $37.7 \pm 24.3 a$ & $40.2 \pm 24.9 a$ & $0.1 \pm 0.1 \mathrm{a}$ & $1.0 \pm 0.0 \mathrm{a}$ & $0.1 \pm 0.1 \mathrm{a}$ \\
\hline & R7 & $103.3 \pm 61.4 a$ & $1.0 \pm 0.0$ & $133.0 \pm 64.2 b$ & $132.5 \pm 68.2 \mathrm{a}$ & $1.2 \pm 0.8 \mathrm{bc}$ & $2.0 \pm 1.0 \mathrm{a}$ & $1.2 \pm 0.8 \mathrm{bc}$ \\
\hline
\end{tabular}

GS, Growth stage of soybean (V2, R1, R3, R5, R7); KA, Kwangan; PS, Poongsannamul; PW, Poongwon; TK, Taekwang. Values are Mean \pm SD from three replications, the significant differences based on Tukey's HDS test $(p \leq 0.05)$ were indicated with different letters.

\subsection{Phylogenetic Structure Analysis}

The sequences of rhizosphere and root nodule bacteria were classified into 36 phyla. Throughout the growth stages, Actinobacteria was the most abundant phyla in the bulk soil and rhizosphere, followed by Alphaproteobacteria, Acidobacteria, and Betaproteobacteria (Figure 3; Figure S3A-D). As the growth stage progressed from the V2 stage, Actinobacteria displayed a tendency to decrease (Figure S3C). The distribution ratio of Alphaproteobacteria increased after the R3 stage while, Acidobacteria decreased after the R3 stage (Figure S3B,C). Bacteroidetes increased the most during the R7 stage except for PS (Figure S3E). Chloroflexi, Firmicutes, Gemmatimonadetes, Deltaproteobacteria, and Gammaproteobacteria showed a tendency to decrease as the growth stage progressed (Figure S3F-J). In root nodule, Alphaproteobacteria showed the highest distribution ratio in the overall soybean growth stage at the phylum level (Figure 4; Figure S4A). Bacteroidetes, Gammaproteobacteria, Betaproteobacteria, Actinobacteria, and Verrucomicrobia showed a tendency to gradually increase as the growth stage progressed (Figure S4B-F). At the genus level, on average, Arthrobacter was the most predominant in bulk soil and rhizosphere, followed by Sphingomonas (Figure 5; Figure S5A,B; Table S2). Although there is a difference in the distribution ratio according to soybean varieties, Aeromicrobium increased in the R1 stage (except for KA), and Flavobacterium increased significantly in R7 stage (Figure S5C,D). Bradyrhizobium was also different for each cultivar but showed a tendency to increase from the R3 stage (excluding PW and TK) (Figure S5E). At the genus level, Bradyrhizobium (75.8-98.4\%) was dominant in root nodules (Figure 6; Figure S6A; Table S2). Looking at the distribution of microorganisms by growth stage except for Bradyrhizobium, the distribution of Bradyrhizobiaceae_unclassified was dominant at the V2 and R1 stages and the same for the 
R3 stage (Figure 6). Unlike the previous stages, the distribution of Rhizobium, Streptomyces, Enterobacter, Spingobacterium, Flavobacterium, and Achromobacter increased from the R3 stage to the R7 stage (Figure S6B-G). Principal component analysis (PCA) results showing the distribution and variation of bacterial communities in the rhizosphere and root nodule of all the growth stages in the four soybean varieties (Figure 7).

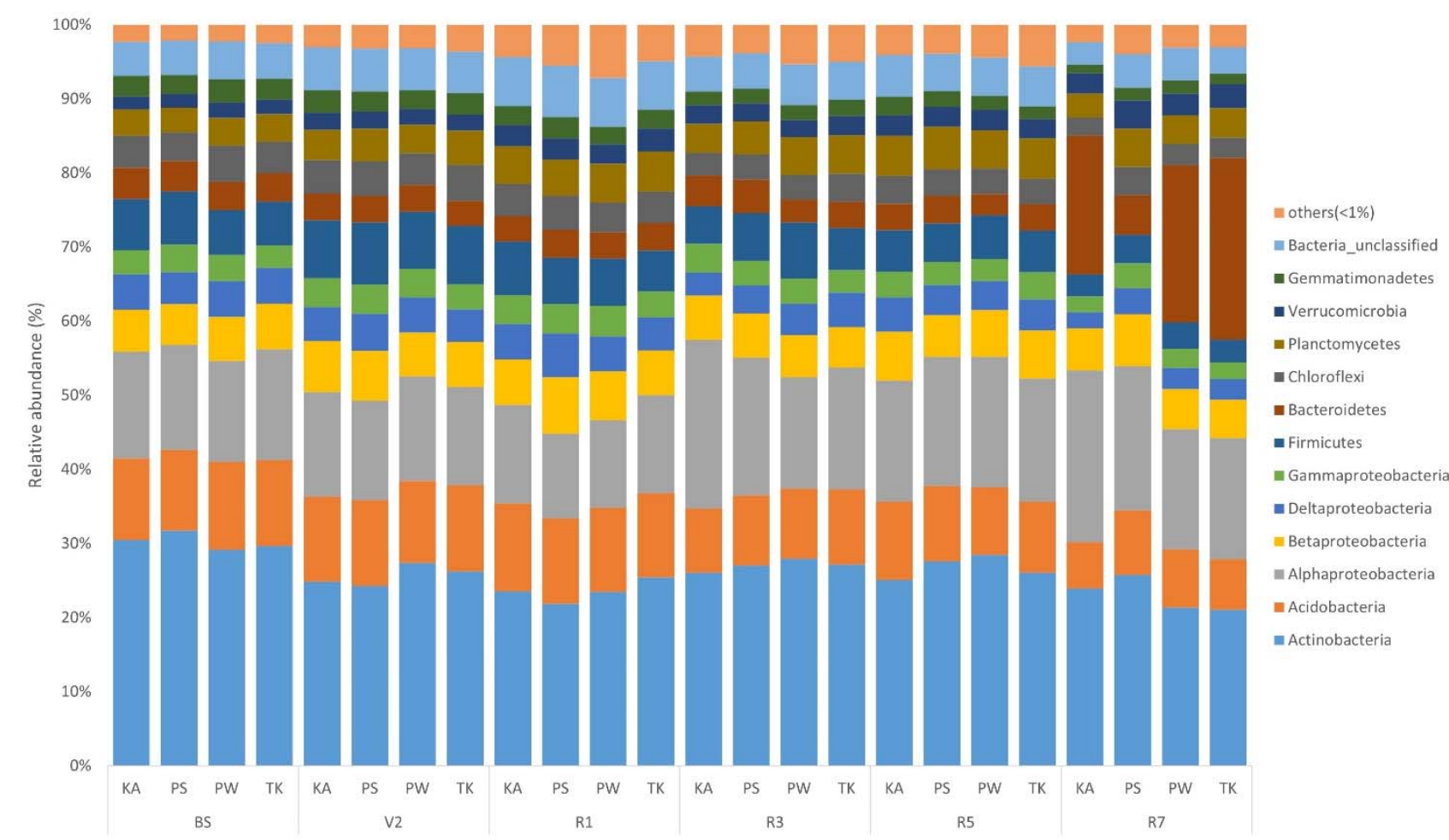

Figure 3. Relative abundance of major phyla in soil before soybean is planted and rhizosphere soil based on the variety and growth stages (V2, R1, R3, R5, R7) of soybean. KA, Kwangan; PS, Poongsannamul; PW, Poongwon; TK, Taekwang. Each bar represents the average relative abundance of triplicates.

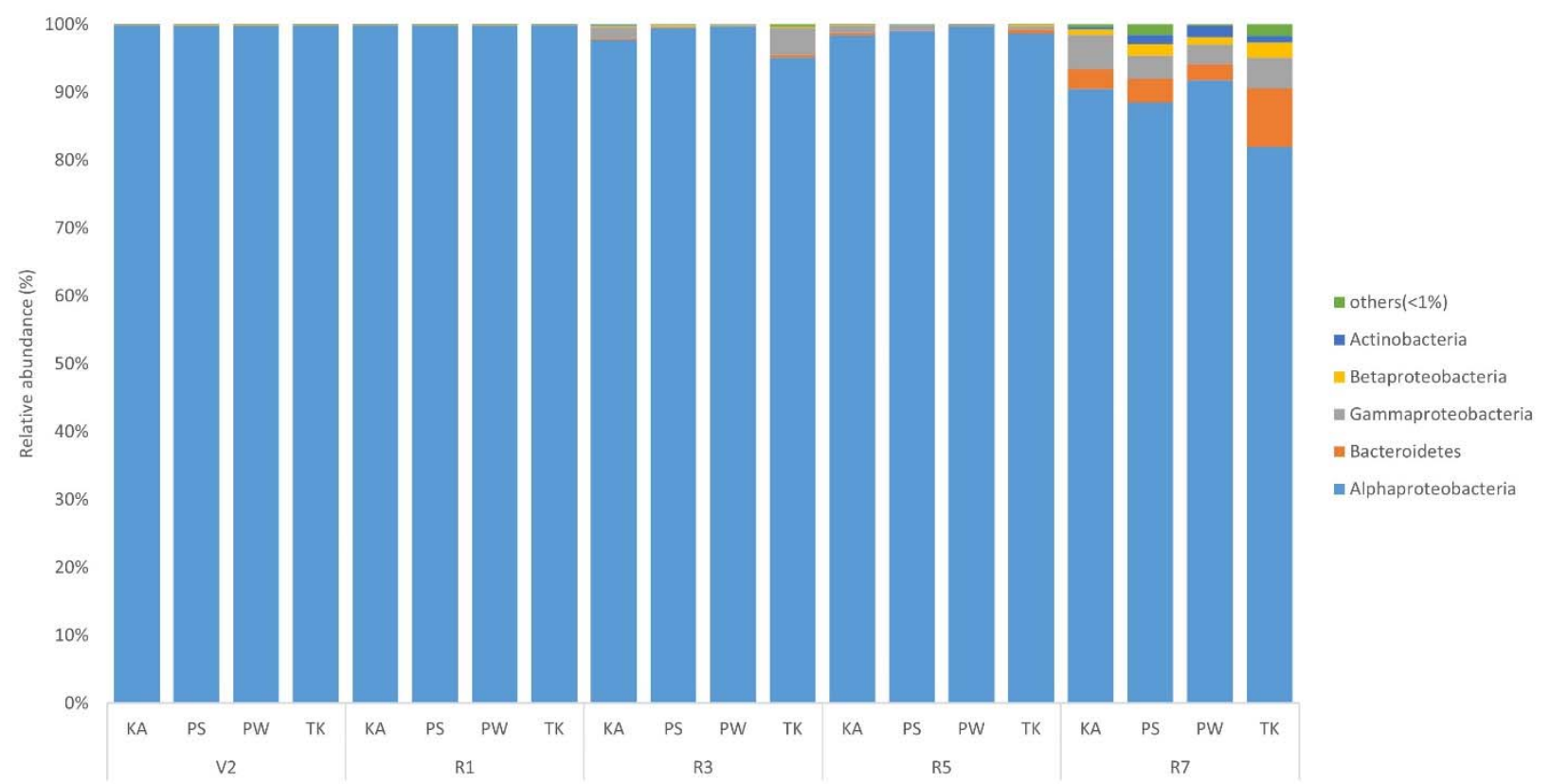

Figure 4. Relative abundance of major phyla presents in root nodule based on the variety and growth stages (V2, R1, R3, R5, R7) of soybean. KA, Kwangan; PS, Poongsannamul; PW, Poongwon; TK, Taekwang. Each bar represents the average relative abundance of triplicates. 


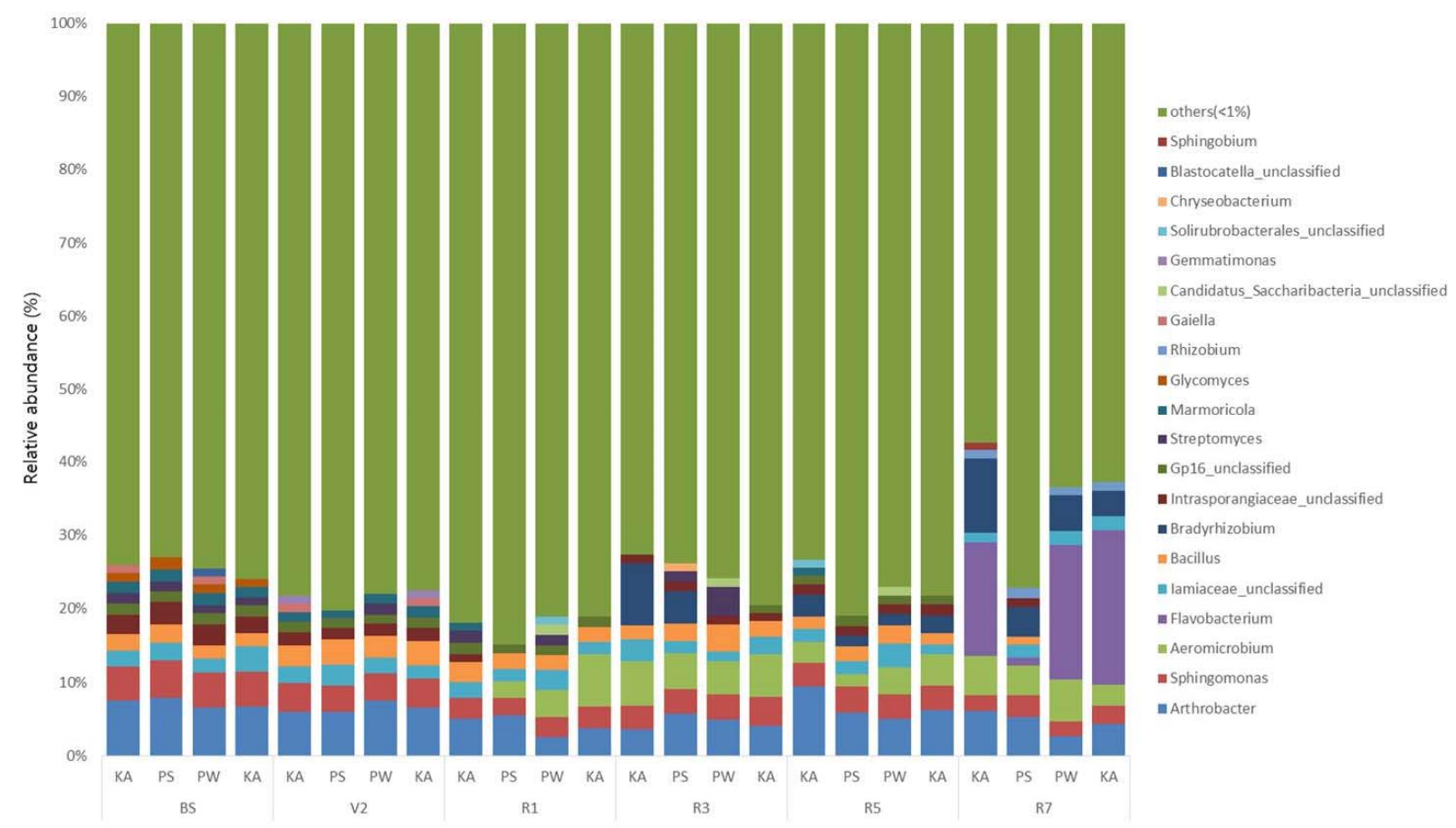

Figure 5. Relative abundance of genus in rhizosphere based on the variety and growth stages (V2, R1, R3, R5, R7) of soybean. KA, Kwangan; PS, Poongsannamul; PW, Poongwon; TK, Taekwang. Each bar represents the average relative abundance of triplicates.

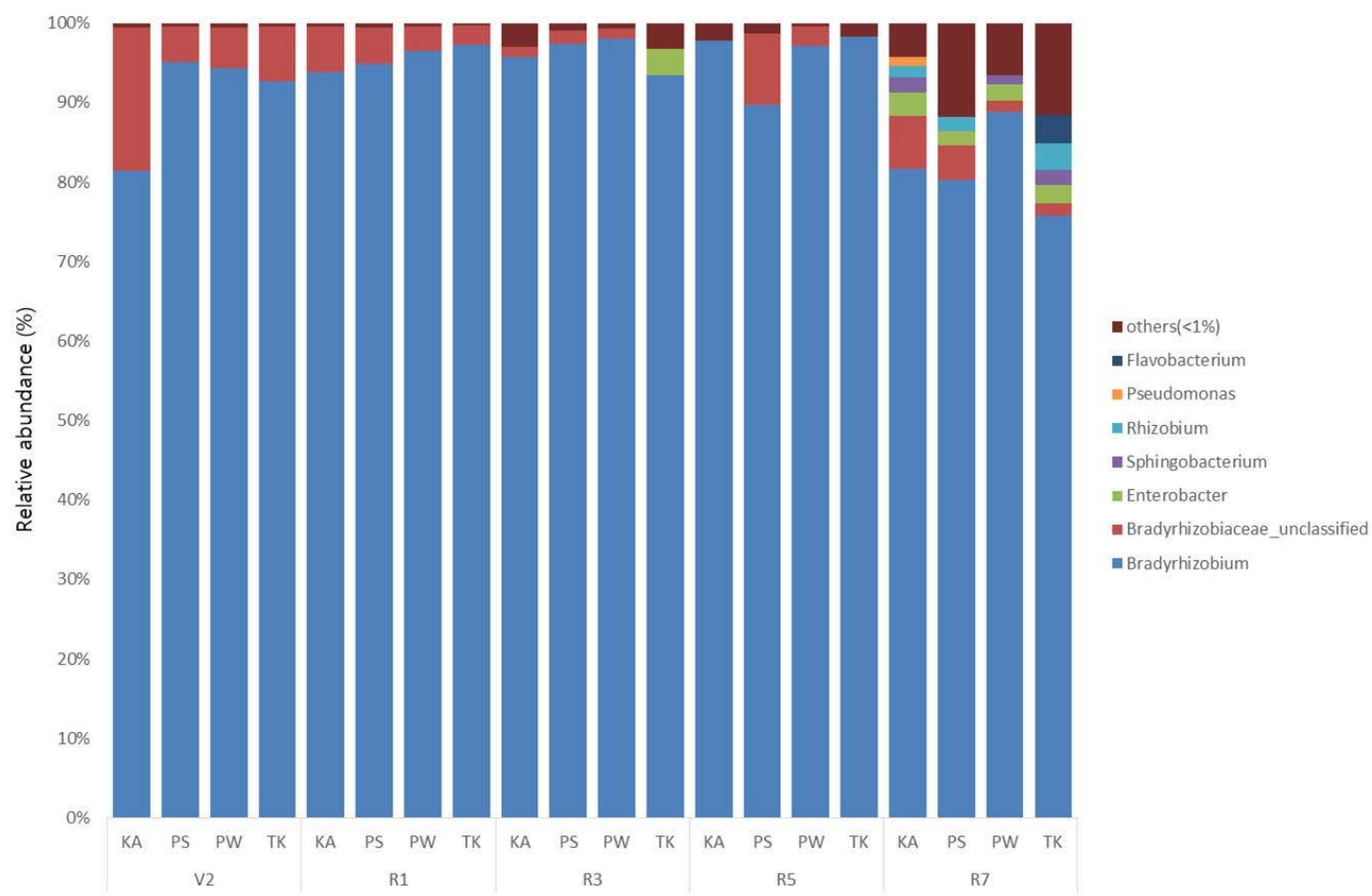

Figure 6. Relative abundance of genus in root nodule based on the growth stages (V2, R1, R3, R5, R7) of soybean. A, B. The bacterial community structure in the bulk soil was different from other growth stages and the stages V2, R1, R3, and R5 of the rhizosphere soil were clustered together; however, the R7 stage is also different from those of other growth stages. These results indicate that after planting the bacterial communities in the soil differed compared to those of bulk soil. Moreover, among the different growth stages the bacterial community composition at the R7 has been differed drastically. 

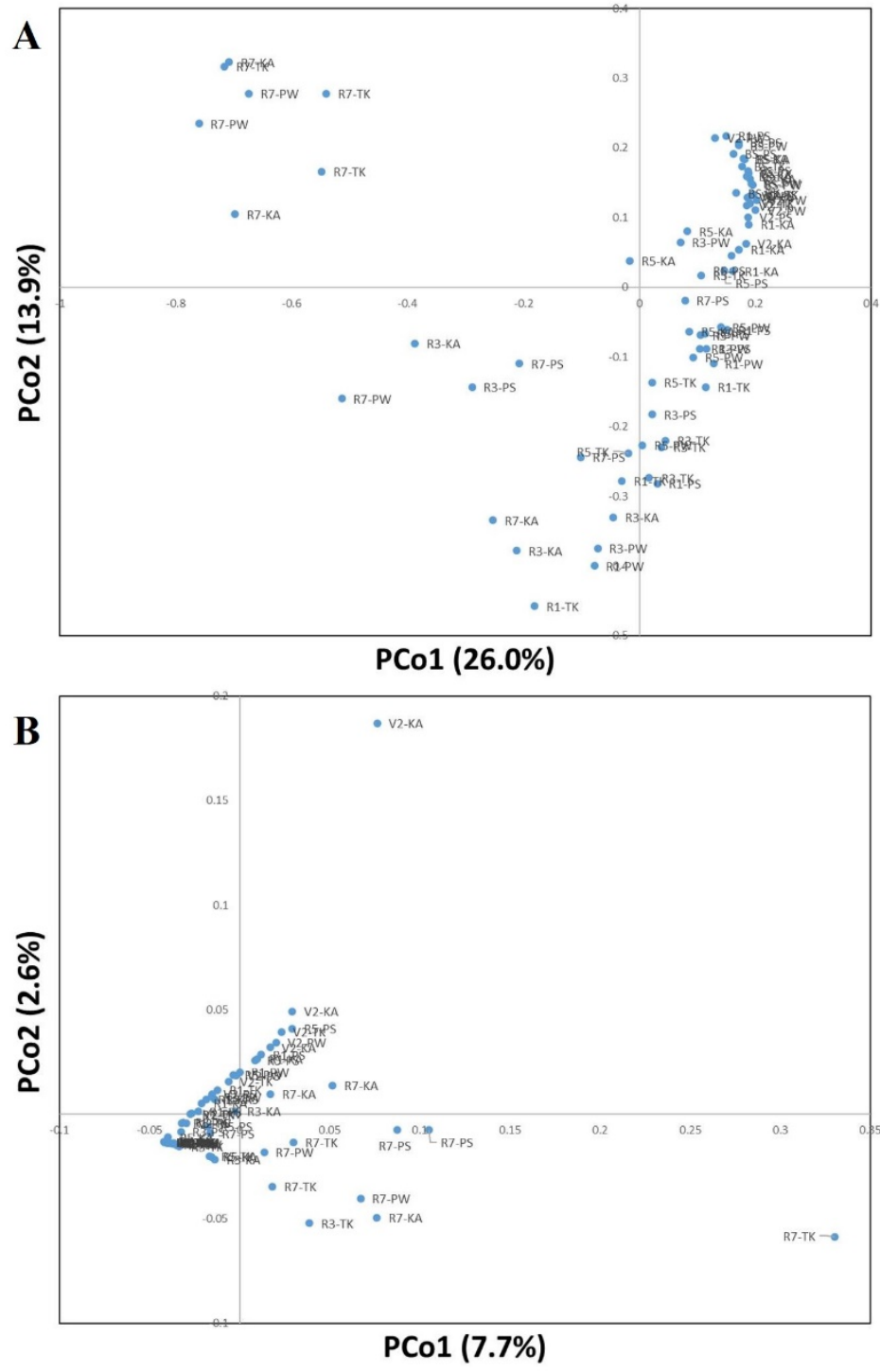

Figure 7. Principal component analysis (PCA) plotted for all the growth stages in the four soybean varieties. PCA results showing the distribution and variation of bacterial communities in the (A), Rhizosphere; (B), Root nodule.

\section{Discussion}

Rhizosphere bacterial communities which are important for the growth and yield of crops are often influenced by the plants $[6,48]$. Since soybean is an important crop, there are few studies on the changes in bacterial communities in the rhizosphere [24]. However, there is no report that comparatively analyzed the bacterial community variation in the rhizosphere and root nodules based on the growth stages of soybean. This is the first study compared the dynamics of bacterial community structures in the rhizosphere and root nodule of four varieties at different growth stages to gain a better understanding of bacterial interactions with soybean. Interestingly, we found that bacterial communities in the rhizosphere soil and root nodules varied in different growth stage and the degree of change differ by varieties also. It is obscure that the timing of significant changes, for instance, from which stage of the growth does the bacterial community changes and whether these changes occur organically in the rhizosphere and root nodule of soybean. Such changes will inevitably affect the seed yield and $\mathrm{N}_{2}$ fixation efficiency, and understanding these changes is critical for the soybean breeding of development of high-yield varieties.

A BioLog assay was used to obtain community-level substrate utilization profiles. According to the results, it is concluded that the soybean cultivar and growth stage had 
an effect on the average well color production (AWCD) of each plate. Except V2 stage, the AWCD of the rhizosphere soil was higher than that of the bulk soil where soybeans were not planted. This is consistent with the findings of Sugiyama et al., [24], who found that the AWCD of the rhizosphere soil is 1.5-3 times that of the bulk soil. Moreover, the activity of soil enzymes tends to increase as the plant grows. In terms of the cultivar, the soil enzyme activity of PW soybean was lower than that of other soybeans. The reason for the variations in soybean cultivar and growth stage should be investigated further. It is expected that the difference in root exudates passing through the root, as a function of cultivar and rearing period, is supposed to result in a difference in rhizosphere soil enzyme activities [24]. However, at the R7 level, there was no difference in soil enzyme activity between cultivars.

The 16S rRNA gene sequencing results depict that both the growth stage and variety had an impact on the dynamics of the bacterial community in the rhizosphere and root nodule. The alpha diversity of the four soybean cultivar at varying growth stages showed conflicting results. More concretely, the Sobs, Chao1, and ACE, along with Shannon, InvSimpson, and NPShannon, increased until the V2 or the R1 stage and then decreased from the R3 to R7 stages (lower than the bulk soil) in the bulk and rhizosphere soil. This suggests that compared with the bulk soil, bacterial richness, and evenness increased in the V2 and R1 stages, and then decreased from the R3 to R7 stages after soybean was planted. It was hypothesized that the diversity of microbes in the rhizosphere soil increases in the early stage of cultivation, but the diversity decreases in the late stage of growth through the peak growth period, and newly dominated bacteria become to reside in rhizosphere. In terms of the alpha diversity at the root nodule, unlike that in the bulk soil and the rhizosphere soil, the species richness index increased over the growth stage. The species diversity index did not exhibit a significant difference from the V2 to R5 stages, but rapidly increased at the R7 stage. This is due to the fact that the number of specific microorganisms involved in plant growth (in particular $\mathrm{N}_{2}$ fixation bacteria) increased at the early stages of growth [49]. However, as the number of bacteria increased significantly in the late growth stage, the species evenness also increased, which is possibly due to the presence of various genera with different functional activities.

In rhizosphere soil, Actinobacteria was most abundantly distributed phylum in bulk and all over the growth stages, followed by Alphaproteobacteria and Acidobacteria. This is consistent with reports of a high abundance of Proteobacteria, Actinobacteria, Bacteroidetes, and Acidobacteria in legumes such as soybean and alfalfa [42,50]. The phylum that showed the greatest change was Bacteroidetes, which showed a significant increase at the R7 stage compared to the V2 stage when soybean root nodules begin to form in soybean varieties except PS cultivar. The distribution ratio of Bacteroidetes differs by soybean variety as well as the growth stage. The phylum Bacteroidetes was classified under the secretion system type IV functional traits which is possibly involved in the symbiotic interactions between bacterial and other organisms in the soybean rhizosphere [22].

OTU-based PCA analyses shown that there are changes in the rhizosphere bacterial communities by stage of soybean growth, which suggests that the formation of a unique bacterial community in the rhizosphere soil by growth stage. In this study, the genera Arthrobacter and Sphingomonas were the most abundant in the rhizosphere. It is reported that Arthrobacter sp. are capable of fixing $\mathrm{N}_{2}$ and solubilizes phosphate to promote the growth of wheat plants [51] and Sphingomonas is known to produce indole-3-acetic acid [52]. Aerobacterium had a higher distribution ratio in soils at the V2, R1, R3, R5, and R7 stages than bulk soil, and showed an increasing trend with the progress of the growth stage. Aeromicrobium is a member of the Actinobacteria family that is present in the soil at a high concentration. Actinobacteria play an important role in resisting disease and promoting growth of plants [53]. Miller et al. [54] reported first that the genus Aeromicrobium produces macrolide antibiotic erythromycin, and based on these results, it was assumed to play an important role in disease suppression. Bradyrhizobium increased as the soybean rearing stage progressed, and its distribution ratio was the highest at the R7 stage. Soybeans have a 
symbiotic relationship with rhizobia, such as Bradyrhizobium japonicum and Bradyrhizobium elkanii, and receive $50-60 \% \mathrm{~N}_{2}$ through the atmospheric $\mathrm{N}_{2}$ fixation at the root nodule. The maximum $\mathrm{N}_{2}$ fixation occurs between the R3 and R5 stages of soybean growth and decreases between the R5 and R7, which are the seed-filling stages [24]. Since, the $\mathrm{N}_{2}$ fixation decreases at the R7 stage, the necessity of Bradyrhizobium, which functions for $\mathrm{N}_{2}$ fixation, at the root nodule is found to decrease compared to the R3 or R5 stages. In this study, the ratio of Bradyrhizobium for the root nodule decreased in the R7 stage, but in the rhizosphere it is found to be increased. Similarly, the increase in Bradyrhizobium in the rhizosphere soil from the V2 to R5 can be attributed to the chemoattractant reaction of the soybean root exudate for $\mathrm{N}_{2}$ fixation.

The distribution ratio of Rhizobium increased at the R7 stage compared to the BS, V2, R1, R3, and R5 stages. Various Rhizobia colonize soybean roots, form root nodules, and provide important benefits to plants through $\mathrm{N}_{2}$ fixation [55]. The genus Rhizobium was also found in wheat and rapeseed roots and is known to account for $2 \%$ of the total bacterial population [56]. Although endophytic rhizobia have been reported in wheat and rapeseed, there was no conclusive evidence that they contribute to symbiotic $\mathrm{N}_{2}$ fixation. Sharma et al. [57] discovered Rhizobium in the root interior of wheat and reported that it increases seedling shoot and root length by producing indole-3-acetic acid. The genus that showed greater change based on the growth stage was Flavobacterium, which showed little change at the bulk soil, V2, R1, R3, and R5 stages but increased significantly at the R7 stage. Flavobacterium has been reported as a PGPR [58]. Although more research is needed on why Flavobacterium increased rapidly at the R7 stage, Flavobacterium was found to be involved in auxin production and P-solubilization. Furthermore, the needs of verifying the effect of Flavobacterium on plant growth and yield needs were reported [58].

In root nodule, the phylum Alphaproteobacteria was exclusively dominant, followed by Bacteroidetes, Gammaproteobacteria, Betaproteobacteria, Actinobacteria, Verrucomicrobia, Firmicutes, and Deltaproteobacteria. In the results of the OTU analysis, Bradyrhizobium was dominant in root nodules all over the growth stages and varieties. In addition, several subdominants $(1-2 \%)$ and a wide variety of rare OTUs were distributed, suggesting the plant-bacterial mutualistic reactions in a unique way. Questions arise about the high diversity of microorganisms in these root nodules and the function of rare OTUs. Furthermore, how such diversity of root nodule microbes can benefit plant resilience and ecosystem stability as the growth stage progresses. Sharaf et al., [59] stated that the functional importance of non-rhizobial bacteria is unknown, but for soybeans, non-rhizobia bacteria would have a significant impact on energetics, symbiosis, and nutrient exchange. The positive effect of Bradyrhizobium sp. on soybean nodulation and of bacterial-fixed $\mathrm{N}_{2}$ on plant tissue incorporation are well-known [60]. It is also known that different Bradyrhizobium species and strains have different effects on growth and yield of the soybean. However, little is known about natural variation in root nodule bacterial communities based on the different growth stages. The symbiotic relationship between $\mathrm{N}_{2}$-fixing bacteria and soybean have developed root nodules as an only ecological niche for $\mathrm{N}_{2}$ fixation. However, concerns exist about the diversity of $\mathrm{N}_{2}$-fixing bacteria in root nodules, as well as whether they can share space with bacteria from other genera or families. Although culture-dependent sampling and microbiome sequencing have described the occurrence of atypical bacterial taxa, biovars, and strains present in root nodule of legumes other than soybean. However, less is understood about how these atypical bacterial communities vary by soybean variety and their functional roles [1].

In this study, there were Bradyrhizobium sp. and other various non-Bradyrhizobium bacteria in the root nodules, which showed a variation according to the soybean variety as well as the stage of soybean growth. In the early stages of growth, Bradyrhizobium sp. was dominant in the root nodules; however, the ratio of non-Bradyrhizobium gradually increased towards the R7 stage, based on the variety. The ratio that non-Bradyrhizobium was accounted for the most in the root nodules was $24.2 \%$ when targeting the rhizosphere soil of one variety (TK) at the R7 stage. According to Sharaf et al. [59], atypical Bradyrhizobium 
sp. reached $\sim 40 \%$, and such diversity comes from isolating pooled plants that incorporated nodules without subdividing the growth stage of soybean varieties. A taxon with the highest distribution ratio in the root nodules was Alphaproteobacteria, and a genus with the most change was Rhizobium excluding Bradyrhizobium. Rhizobia colonize soybeans and form root nodules, which offer essential benefits of plants by fixing nitrogen [61].

A phylum with the greatest change of the distribution ratio in the root nodules following Alphaproteobacteria was Bacteroidetes and Gammaproteobacteria, and the genera that showed great change were Flavobacterium (Bacteroidetes) and Pseudomonas (Gammaproteobacteria). The Flavobacterium sp. IR29-16 and other strains have been reported to contribute significantly to the growth of plant roots in length through IAA production [62]. Pseudomonas was known to produce siderophore. Siderophore does not appear to have a direct effect on promoting plant growth, but the majority of seed endophytes have this trait, indicating that they play an important role in plant development. Fluorescent Pseudomonas can colonize a variety of ecological niches, which is reflected in their iron uptake system with a high degree of diversity [63]. Endophytes that produce siderophores like Pseudomonas strain have a selective advantage over other bacteria or pathogens by stealing their irons $[64,65]$. Gammaproteobacteria are a phylum that also showed a big difference in root nodules by stage of soybean growth. Enterobacter, which also belongs to Gammaproteobacteria, is an OTU whose relative frequency is increased in root nodules than rhizosphere. Free-living Enterobacter has been reported to be capable of nitrogen fixation, and certain species, such as E. cloacae, have been involved in nitrogen fixation in plants and isolated from the rhizospheres of wheat, sorghum, and rice. Enterobacteria in rhizosphere are known to solubilize organic phosphorus with phosphate and support plant availability [66,67]. Serratia sp., which also belongs to Gammaproteobacteria, is an OTU whose relative frequency is increased in root nodules than rhizosphere. Serratia sp. have been reported to enhance soybean nodulation by Bradyrhizobium, which is the evidence that Serratia promotes Bradyrhizobium growth by producing Fe-chelates [68-70].

Other than Gammaproteobacteria, phylum Betaproteobacteria was found with the greatest change in the root nodules based on the growth stage. The genus showing the greatest variations in the phyla Betaproteobacteria was Achromobacter. The Achromobacter spp. have been reported to exist in soils [13] and plants [71]. Although they are associated with several clinical diseases as human pathogens, many Achromobacter strains have been reported to have PGP properties in the literatures [71,72]. For example, Achromobacter sp. strain EMCC1936 can produce IAA, gibberellin, and solubilizing rock phosphate and increase vegetative growth and yield parameter of tomatoes based on in vitro analyses and a greenhouse experiment [73]. Genus Variovorax showed an increased frequency in the root nodules at the R7 stage. Similarly, Variovorax has been reported to appear at a high frequency in the rhizosphere and root of canola [74,75]. Mycobacterium, a rare bacterium that belongs to Actinobacteria, is also found in soybean root nodules. This genus is known to have numerous interactions with other taxa, suggesting that rare but essential species can play an important role through dense connection with other groups [22]. Consistently and highly linked bacterial taxa with other groups play a potentially important role in community structures and ecological functions [76]. The root nodules were initially dominated by bacteria that play a key role in nitrogen fixation and gradually shifted to microbes that were functionally diverse on the late stage of growth. Streptomyces, a genus that belongs to the same Actinobacteria and is distributed in root nodules, is known to reduce infection of pine roots by Fusarium sp. and Armillaria sp. As for Microbacterium that belongs to the same Actinobacteria, Microbacterium sp. P27 is known to have indole-3-acetic acid production, ammonia production, and 1-aminocyclopropane-a-carboxylate deaminase activity [77]. Verrucomicrobia is a phylum that showed the next greatest change, and Verrucomicrobium showed the greatest change among the genera that belong to this phylum. The reason for a high abundance at the R7 stage in the root nodules remains unknown, but an oligotroph like Verrucomicrobia and Acidobacteria is known to be more abundant in soils with poor nutrients [78]. Paenibacilli that belong to Firmicutes were abundant in the 
root nodules at the R7 stage and are known to reduce water-deficit stress in a legume by reducing stress-signaling hormones [79].

\section{Conclusions}

In conclusion, the dynamics of bacterial community structure in soybean rhizosphere and root nodules exhibited great variations based on their variety and growth stage, which both high-throughput sequencing technology and the BioLog EcoPlate assay confirmed. According to physiological activities assessed by the BioLog assay, the metabolic capabilities of rhizosphere soil were higher than bulk soil during the growth stages. Further, the dynamics of bacterial communities were varied between bulk soil and rhizosphere based on the growth stages and varieties of soybean. Especially, it has few PGPR genera which are highly abundant and specific to the growth stages. The root nodule specific bacterial communities also found to be differed according to the growth stages and the variety. This study sheds light on the effective bacterial community structure variation on the field which could be useful for the future utilization of microbial resources in leguminous plants. Further investigations will decipher mechanisms underlying the dynamics of community composition in both rhizosphere and root nodules and their involvement in other functions, which is important for the development of elite soybean varieties.

Supplementary Materials: The following are available online at https:/ /www.mdpi.com/article/10 .3390 /ijms22115577/s1; Figure S1: Bacterial diversity indices of bulk soil and rhizosphere of four soybean varieties. Figure S2: Bacterial diversity indices of root nodules of four soybean varieties. Figure S3: Influence of varieties and growth stages in the dominant phylum present in bulk soil and rhizosphere of soybean. Figure S4: Influence of varieties and growth stages in the dominant phylum present in root nodules of soybean. Figure S5: Influence of varieties and growth stages in the dominant genera present in bulk soil and rhizosphere of soybean. Figure S6: Influence of varieties and growth stages in the dominant genera present in root nodules of soybean. Table S1. Substrate utilization indicated by color development in Biolog Eco Plates. Table S2. Overall OTUs identified from the sequencing reads.

Author Contributions: Conceptualization, S.-I.S. and Y.-J.O.; methodology, J.-H.A., E.-K.S., and H.-J.K.; software, S.-I.S. and J.-H.A.; validation, W.-S.C., and Y.-S.C.; formal analysis, S.P. and K.-S.S.; data curation, Y.-J.O. and J.-H.A.; writing—original draft preparation, S.-I.S.; writing—review and editing, S.-I.S., J.-H.A., and S.P.; project administration, S.-I.S.; funding acquisition, S.-I.S. All authors have read and agreed to the published version of the manuscript.

Funding: This study was supported by the Research Program for Agricultural Science \& Technology Development (Project No. PJ011911062016), National Institute of Agricultural Sciences, Rural Development Administration, Republic of Korea.

Institutional Review Board Statement: Not applicable.

Informed Consent Statement: Not applicable.

Data Availability Statement: Not applicable.

Conflicts of Interest: The authors declare no conflict of interest.

\section{References}

1. Sugiyama, A. The soybean rhizosphere: Metabolites, microbes, and beyond-A review. J. Adv. Res. 2019, 19, 67-73. [CrossRef] [PubMed]

2. Qiu, L.-J.; Chen, P.-Y.; Liu, Z.-X.; Li, Y.-H.; Guan, R.-X.; Wang, L.-H.; Chang, R.-Z. The worldwide utilization of the Chinese soybean germplasm collection. Plant Genet. Resour. 2011, 9, 109-122. [CrossRef]

3. USDA Foreign Agricultural Service. Available online: http://www.fas.usda.gov (accessed on 23 September 2020).

4. Bhardwaj, D.; Ansari, M.W.; Sahoo, R.K.; Tuteja, N. Biofertilizers function as key player in sustainable agriculture by improving soil fertility, plant tolerance and crop productivity. Microb. Cell Fact. 2014, 13, 66. [CrossRef]

5. Bais, H.P.; Weir, T.L.; Perry, L.G.; Gilroy, S.; Vivanco, J.M. The role of root exudates in rhizosphere interactions with plants and other organisms. Annu. Rev. Plant Biol. 2006, 57, 233-266. [CrossRef] [PubMed]

6. Berendsen, R.L.; Pieterse, C.M.J.; Bakker, P.A.H.M. The rhizosphere microbiome and plant health. Trends Plant Sci. 2012, 17, 478-486. [CrossRef] [PubMed] 
7. Turner, T.R.; James, E.K.; Poole, P.S. The plant microbiome. Genome Biol. 2013, 14, 1-10. [CrossRef] [PubMed]

8. Moe, L.A. Amino acids in the rhizosphere: From plants to microbes. Am. J. Bot. 2013, 100, 1692-1705. [CrossRef] [PubMed]

9. Lakshmanan, V.; Selvaraj, G.; Bais, H.P. Functional soil microbiome: Belowground solutions to an aboveground problem. Plant Physiol. 2014, 166, 689-700. [CrossRef] [PubMed]

10. De-La-Peña, C.; Loyola-Vargas, V.M. Biotic interactions in the rhizosphere: A diverse cooperative enterprise for plant productivity. Plant Physiol. 2014, 166, 701-719. [CrossRef]

11. Tkacz, A.; Poole, P. Role of root microbiota in plant productivity. J. Exp. Bot. 2015, 66, 2167-2175. [CrossRef]

12. Pinton, R.; Varanini, Z.; Nannipieri, P. The Rhizosphere: Biochemistry and Organic Substances at the Soil-Plant Interface, 2nd ed.; Marcel Dekker: New York, NY, USA, 2001.

13. Morgan, J.A.W.; Bending, G.D.; White, P.J. Biological costs and benefits to plant-microbe interactions in the rhizosphere. J. Exp. Bot. 2005, 56, 1729-1739. [CrossRef] [PubMed]

14. Huang, X.-F.; Chaparro, J.M.; Reardon, K.; Zhang, R.; Shen, Q.; Vivanco, J.M. Rhizosphere interactions: Root exudates, microbes, and microbial communities. Botany 2014, 92, 267-275. [CrossRef]

15. Lundberg, D.S.; Lebeis, S.L.; Paredes, S.H.; Yourstone, S.; Gehring, J.; Malfatti, S.; Tremblay, J.; Engelbrektson, A.; Kunin, V.; Del Rio, T.G.; et al. Defining the core Arabidopsis thaliana root microbiome. Nat. Cell Biol. 2012, 488, 86-90. [CrossRef] [PubMed]

16. Schlaeppi, K.; Dombrowski, N.; Oter, R.G.; van Themaat, E.V.L.; Schulze-Lefert, P. Quantitative divergence of the bacterial root microbiota in Arabidopsis thaliana relatives. Proc. Natl. Acad. Sci. USA 2014, 111, 585-592. [CrossRef] [PubMed]

17. Bakker, P.A.; Pieterse, C.M.; De Jonge, R.; Berendsen, R.L. The soil-borne legacy. Cell 2018, 172, 1178-1180. [CrossRef] [PubMed]

18. Bakker, P.A.; Doornbos, R.F.; Zamioudis, C.; Berendsen, R.L.; Pieterse, C.M. Induced systemic resistance and the rhizosphere microbiome. Plant Pathol. J. 2013, 29, 136-143. [CrossRef]

19. Mendes, R.; Garbeva, P.; Raaijmakers, J.M. The rhizosphere microbiome: Significance of plant beneficial, plant pathogenic, and human pathogenic microorganisms. FEMS Microbiol. Rev. 2013, 37, 634-663. [CrossRef]

20. Mendes, L.W.; Braga, L.P.P.; Navarrete, A.A.; de Souza, D.G.; Silva, G.G.Z.; Tsai, S.M. Using metagenomics to connect microbial community biodiversity and functions. Curr. Issues Mol. Biol. 2017, 24, 103-118. [CrossRef] [PubMed]

21. Castrillo, G.; Teixeira, P.J.; Paredes, S.H.; Law, T.F.; De Lorenzo, L.; Feltcher, M.E.; Finkel, O.M.; Breakfield, N.W.; Mieczkowski, P.; Jones, P.M.C.D.; et al. Root microbiota drive direct integration of phosphate stress and immunity. Nat. Cell Biol. 2017, 543, 513-518. [CrossRef]

22. Mendes, L.W.; Kuramae, E.E.; Navarrete, A.A.; Van Veen, J.A.; Tsai, S.M. Taxonomical and functional microbial community selection in soybean rhizosphere. ISME J. 2014, 8, 1577-1587. [CrossRef]

23. Fitzpatrick, C.R.; Copeland, J.; Wang, P.W.; Guttman, D.S.; Kotanen, P.M.; Johnson, M.T.J. Assembly and ecological function of the root microbiome across angiosperm plant species. Proc. Natl. Acad. Sci. USA 2018, 115, E1157-E1165. [CrossRef] [PubMed]

24. Sugiyama, A.; Ueda, Y.; Zushi, T.; Takase, H.; Yazaki, K. Changes in the bacterial community of soybean rhizospheres during growth in the field. PLoS ONE 2014, 9, e100709. [CrossRef] [PubMed]

25. Badri, D.V.; Weir, T.L.; van der Lelie, D.; Vivanco, J.M. Rhizosphere chemical dialogues: Plant-microbe interactions. Curr. Opin. Biotechnol. 2009, 20, 642-650. [CrossRef] [PubMed]

26. Badri, D.V.; Chaparro, J.M.; Zhang, R.; Shen, Q.; Vivanco, J.M. Application of natural blends of phytochemicals derived from the root exudates of Arabidopsis to the soil reveal that phenolic-related compounds predominantly modulate the soil microbiome. $J$. Biol. Chem. 2013, 288, 4502-4512. [CrossRef] [PubMed]

27. Chaparro, J.M.; Badri, D.V.; Bakker, M.G.; Sugiyama, A.; Manter, D.K.; Vivanco, J.M. Root exudation of phytochemicals in arabidopsis follows specific patterns that are developmentally programmed and correlate with soil microbial functions. PLoS ONE 2013, 8, e55731. [CrossRef]

28. Vandenkoornhuyse, P.; Quaiser, A.; Duhamel, M.; Le Van, A.; Dufresne, A. The importance of the microbiome of the plant holobiont. New Phytol. 2015, 206, 1196-1206. [CrossRef] [PubMed]

29. Lu, T.; Ke, M.; Lavoie, M.; Jin, Y.; Fan, X.; Zhang, Z.; Fu, Z.; Sun, L.; Gillings, M.; Peñuelas, J.; et al. Rhizosphere microorganisms can influence the timing of plant flowering. Microbiome 2018, 6, 1-12. [CrossRef]

30. Saleem, M.; Law, A.D.; Sahib, M.R.; Pervaiz, Z.H.; Zhang, Q. Impact of root system architecture on rhizosphere and root microbiome. Rhizosphere 2018, 6, 47-51. [CrossRef]

31. Garbeva, P.; Van Elsas, J.D.; Van Veen, J.A. Rhizosphere microbial community and its response to plant species and soil history. Plant. Soil 2007, 302, 19-32. [CrossRef]

32. Schlemper, T.R.; Leite, M.F.A.; Lucheta, A.R.; Shimels, M.; Bouwmeester, H.J.; Van Veen, J.A.; Kuramae, E.E. Rhizobacterial community structure differences among sorghum cultivars in different growth stages and soils. FEMS Microbiol. Ecol. 2017, 93, 1-11. [CrossRef]

33. Qiao, Q.; Wang, F.; Zhang, J.; Chen, Y.; Zhang, C.; Liu, G.; Zhang, H.; Ma, C.; Zhang, J. The variation in the rhizosphere microbiome of cotton with soil type, genotype and developmental stage. Sci. Rep. 2017, 7, 1-10. [CrossRef] [PubMed]

34. Bulgarelli, D.; Rott, M.; Schlaeppi, K.; Van Themaat, E.V.L.; Ahmadinejad, N.; Assenza, F.; Rauf, P.; Huettel, B.; Reinhardt, R.; Schmelzer, E.; et al. Revealing structure and assembly cues for Arabidopsis root-inhabiting bacterial microbiota. Nat. Cell Biol. 2012, 488, 91-95. [CrossRef] [PubMed]

35. Bulgarelli, D.; Garrido-Oter, R.; Münch, P.C.; Weiman, A.; Dröge, J.; Pan, Y.; McHardy, A.C.; Schulze-Lefert, P. Structure and function of the bacterial root microbiota in wild and domesticated barley. Cell Host Microbe 2015, 17, 392-403. [CrossRef] [PubMed] 
36. Aira, M.; Gómez-Brandón, M.; Lazcano, C.; Bååth, E.; Domínguez, J. Plant genotype strongly modifies the structure and growth of maize rhizosphere microbial communities. Soil Biol. Biochem. 2010, 42, 2276-2281. [CrossRef]

37. Liang, J.; Sun, S.; Ji, J.; Wu, H.; Meng, F.; Zhang, M.; Zheng, X.; Wu, C.; Zhang, Z. Comparison of the rhizosphere bacterial communities of zigongdongdou soybean and a high-methionine transgenic line of this cultivar. PLoS ONE 2014, 9, e103343. [CrossRef]

38. Newman, M.M.; Hoilett, N.; Lorenz, N.; Dick, R.P.; Liles, M.; Ramsier, C.; Kloepper, J.W. Glyphosate effects on soil rhizosphereassociated bacterial communities. Sci. Total. Environ. 2016, 543, 155-160. [CrossRef] [PubMed]

39. Okutani, F.; Hamamoto, S.; Aoki, Y.; Nakayasu, M.; Nihei, N.; Nishimura, T.; Yazaki, K.; Sugiyama, A. Rhizosphere modelling reveals spatiotemporal distribution of daidzein shaping soybean rhizosphere bacterial community. Plant. Cell Environ. 2020, 43, 1036-1046. [CrossRef]

40. Albrecht, S.L.; Maier, R.J.; Hanus, F.J.; Russell, S.A.; Emerich, D.W.; Evans, H.J. Hydrogenase in Rhizobium japonicum increases nitrogen fixation by nodulated soybeans. Science 1979, 203, 1255-1257. [CrossRef]

41. Williams, L.E.; Phillips, D.A. Increased soybean productivity with a Rhizobium japonicum mutant 1. Crop. Sci. 1983, 23, 246-250. [CrossRef]

42. Xiao, X.; Chen, W.; Zong, L.; Yang, J.; Jiao, S.; Lin, Y.; Wang, E.; Wei, G. Two cultivated legume plants reveal the enrichment process of the microbiome in the rhizocompartments. Mol. Ecol. 2017, 26, 1641-1651. [CrossRef] [PubMed]

43. Wigley, K.; Moot, D.; Wakelin, S.A.; Laugraud, A.; Blond, C.; Seth, K.; Ridgway, H. Diverse bacterial taxa inhabit root nodules of lucerne (Medicago sativa L.) in New Zealand pastoral soils. Plant. Soil 2017, 420, 253-262. [CrossRef]

44. Martínez-Hidalgo, P.; Hirsch, A.M. The nodule microbiome: $\mathrm{N}_{2}$-fixing Rhizobia do not live alone. Phytobiomes J. 2017, 1, 70-82. [CrossRef]

45. Somasegaran, P.; Hoben, H.J. Collecting nodules and isolating rhizobia. In Handbook for Rhizobia; Springer: Yew York, NY, USA, 1994; pp. 7-23.

46. Garland, J.L.; Mills, A.L. Classification and characterization of heterotrophic microbial communities on the basis of patterns of community-level sole-carbon-source utilization. Appl. Environ. Microbiol. 1991, 57, 2351-2359. [CrossRef] [PubMed]

47. Wei, M.; Tan, F.; Zhu, H.; Cheng, K.; Wu, X.; Wang, J.; Zhao, K.; Tang, X. Impact of Bt-transgenic rice (SHK601) on soil ecosystems in the rhizosphere during crop development. Plant. Soil Environ. 2012, 58, 217-223. [CrossRef]

48. Uroz, S.; Buée, M.; Murat, C.; Frey-Klett, P.; Martin, F. Pyrosequencing reveals a contrasted bacterial diversity between oak rhizosphere and surrounding soil. Environ. Microbiol. Rep. 2010, 2, 281-288. [CrossRef]

49. Suleiman, M.K.; Dixon, K.; Commander, L.; Nevill, P.; Quoreshi, A.M.; Bhat, N.R.; Manuvel, A.J.; Sivadasan, M.T. Assessment of the diversity of fungal community composition associated with Vachellia pachyceras and its rhizosphere soil from Kuwait desert. Front. Microbiol. 2019, 10, 63. [CrossRef] [PubMed]

50. Wang, C.; Wu, B.; Jiang, K.; Wei, M.; Wang, S. Effects of different concentrations and types of $\mathrm{Cu}$ and Pb on soil N-fixing bacterial communities in the wheat rhizosphere. Appl. Soil Ecol. 2019, 144, 51-59. [CrossRef]

51. Kumar, A.; Maurya, B.; Raghuwanshi, R. Isolation and characterization of PGPR and their effect on growth, yield and nutrient content in wheat (Triticum aestivum L.). Biocatal. Agric. Biotechnol. 2014, 3, 121-128. [CrossRef]

52. Tsavkelova, E.A.; Cherdyntseva, T.A.; Botina, S.G.; Netrusov, A. Bacteria associated with orchid roots and microbial production of auxin. Microbiol. Res. 2007, 162, 69-76. [CrossRef] [PubMed]

53. Palaniyandi, S.A.; Yang, S.H.; Damodharan, K.; Suh, J.-W. Genetic and functional characterization of culturable plant-beneficial actinobacteria associated with yam rhizosphere. J. Basic Microbiol. 2013, 53, 985-995. [CrossRef]

54. Miller, E.S.; Woese, C.R.; Brenner, S. Description of the erythromycin-producing bacterium Arthrobacter sp. strain NRRL B-3381 as Aeromicrobium erythreum gen. nov., sp. nov. Int. J. Syst. Bacteriol. 1991, 41, 363-368. [CrossRef] [PubMed]

55. Liu, C.-W.; Breakspear, A.; Guan, D.; Cerri, M.R.; Jackson, K.; Jiang, S.; Robson, F.; Radhakrishnan, G.V.; Roy, S.; Bone, C.; et al. NIN acts as a network hub controlling a growth module required for rhizobial infection. Plant. Physiol. 2019, 179, 1704-1722. [CrossRef] [PubMed]

56. Lupwayi, N.Z.; Clayton, G.W.; Hanson, K.G.; Rice, W.A.; Biederbeck, V.O. Endophytic rhizobia in barley, wheat and canola roots. Can. J. Plant. Sci. 2004, 84, 37-45. [CrossRef]

57. Sharma, P.K.; Sarita, S.; Prell, J. Isolation and characterization of an endophytic bacterium related to Rhizobium/Agrobacterium from wheat (Triticum aestivum L.) roots. Curr. Sci. 2005, 89, 608-613.

58. Soltani, A.-A.; Khavazi, K.; Asadi-Rahmani, H.; Omidvari, M.; Dahaji, P.A.; Mirhoseyni, H. Plant growth promoting characteristics in some Flavobacterium spp. isolated from soils of Iran. J. Agric. Sci. 2010, 2, p106. [CrossRef]

59. Sharaf, H.; Rodrigues, R.R.; Moon, J.; Zhang, B.; Mills, K.; Williams, M.A. Unprecedented bacterial community richness in soybean nodules vary with cultivar and water status. Microbiome 2019, 7, 1-18. [CrossRef] [PubMed]

60. Caldwell, B.E.; Vest, G. Effects of Rhizobium japonicum strains on soybean yields. Crop. Sci. 1970, 10, 19-21. [CrossRef]

61. Bulgarelli, D.; Schlaeppi, K.; Spaepen, S.; Van Themaat, E.V.L.; Schulze-Lefert, P. Structure and functions of the bacterial microbiota of plants. Annu. Rev. Plant. Biol. 2013, 64, 807-838. [CrossRef] [PubMed]

62. Patten, C.L.; Glick, B.R. Role of Pseudomonas putida indoleacetic acid in development of the host plant root system. Appl. Environ. Microbiol. 2002, 68, 3795-3801. [CrossRef]

63. Cornelis, P.; Matthijs, S. Diversity of siderophore-mediated iron uptake systems in fluorescent pseudomonads: Not only pyoverdines. Environ. Microbiol. 2002, 4, 787-798. [CrossRef] 
64. Compant, S.; Reiter, B.; Sessitsch, A.; Nowak, J.; Clément, C.; Barka, E.A. Endophytic colonization of Vitis vinifera L. by plant growth-promoting bacterium Burkholderia sp. strain PsJN. Appl. Environ. Microbiol. 2005, 71, 1685-1693. [CrossRef] [PubMed]

65. Compant, S.; Clément, C.; Sessitsch, A. Plant growth-promoting bacteria in the rhizo- and endosphere of plants: Their role, colonization, mechanisms involved and prospects for utilization. Soil Biol. Biochem. 2010, 42, 669-678. [CrossRef]

66. Rodríguez, H.; Fraga, R. Phosphate solubilizing bacteria and their role in plant growth promotion. Biotechnol. Adv. 1999, 17, 319-339. [CrossRef]

67. Kuklinsky-Sobral, J.; Araújo, W.L.; Mendes, R.; Geraldi, I.O.; Pizzirani-Kleiner, A.A.; Azevedo, J.L. Isolation and characterization of soybean-associated bacteria and their potential for plant growth promotion. Environ. Microbiol. 2004, 6, 1244-1251. [CrossRef]

68. Polonenko, D.R.; Scher, F.M.; Kloepper, J.W.; Singleton, C.A.; Laliberte, M.; Zaleska, I. Effects of root colonizing bacteria on nodulation of soybean roots by Bradyrhizobium japonicum. Can. J. Microbiol. 1987, 33, 498-503. [CrossRef]

69. Plessner, O.; Klapatch, T.; Guerinot, M.L. Siderophore Utilization by Bradyrhizobium japonicum. Appl. Environ. Microbiol. 1993, 59, 1688-1690. [CrossRef] [PubMed]

70. Zhang, F.; Dashti, N.; Hynes, R.K.; Smith, D.L. Plant growth promoting Rhizobacteria and soybean [Glycine max (L.) Merr.] nodulation and nitrogen fixation at suboptimal root zone temperatures. Ann. Bot. 1996, 77, 453-460. [CrossRef]

71. Jha, P.; Kumar, A. Characterization of novel plant growth promoting endophytic bacterium Achromobacter xylosoxidans from wheat plant. Microb. Ecol. 2009, 58, 179-188. [CrossRef]

72. Dawwam, G.E.; Elbeltagy, A.; Emara, H.M.; Abbas, I.H.; Hassan, M.M. Beneficial effect of plant growth promoting bacteria isolated from the roots of potato plant. Ann. Agric. Sci. 2013, 58, 195-201. [CrossRef]

73. Abdel-Rahman, H.M.; Salem, A.A.; Moustafa, M.M.A.; El-Garhy, H.A.S. A novice Achromobacter sp. EMCC1936 strain acts as a plant-growth-promoting agent. Acta Physiol. Plant. 2017, 39, 61. [CrossRef]

74. De Campos, S.B.; Youn, J.-W.; Farina, R.; Jaenicke, S.; Jünemann, S.; Szczepanowski, R.; Beneduzi, A.; Vargas, L.; Goesmann, A.; Wendisch, V.F.; et al. Changes in root bacterial communities associated to two different development stages of canola (Brassica napus L. var oleifera) evaluated through next-generation sequencing technology. Microb. Ecol. 2013, 65, 593-601. [CrossRef] [PubMed]

75. Croes, S.; Weyens, N.; Janssen, J.; Vercampt, H.; Colpaert, J.; Carleer, R.; Vangronsveld, J. Bacterial communities associated with Brassica napus L. grown on trace element-contaminated and non-contaminated fields: A genotypic and phenotypic comparison. Microb. Biotechnol. 2013, 6, 371-384. [CrossRef] [PubMed]

76. Agler, M.T.; Ruhe, J.; Kroll, S.; Morhenn, C.; Kim, S.-T.; Weigel, D.; Kemen, E.M. Microbial hub taxa link host and abiotic factors to plant microbiome variation. PLoS Biol. 2016, 14, e1002352. [CrossRef] [PubMed]

77. Singh, T.; Singh, D.K. Rhizospheric Microbacterium sp. P27 showing potential of lindane degradation and plant growth promoting Traits. Curr. Microbiol. 2019, 76, 888-895. [CrossRef] [PubMed]

78. Pérez-Jaramillo, J.E.; Mendes, R.; Raaijmakers, J.M. Impact of plant domestication on rhizosphere microbiome assembly and functions. Plant. Mol. Biol. 2016, 90, 635-644. [CrossRef] [PubMed]

79. Figueiredo, M.V.; Burity, H.A.; Martinez, C.; Chanway, C.P. Alleviation of drought stress in the common bean (Phaseolus vulgaris L.) by co-inoculation with Paenibacillus polymyxa and Rhizobium tropici. Appl. Soil Ecol. 2008, 40, 182-188. [CrossRef] 